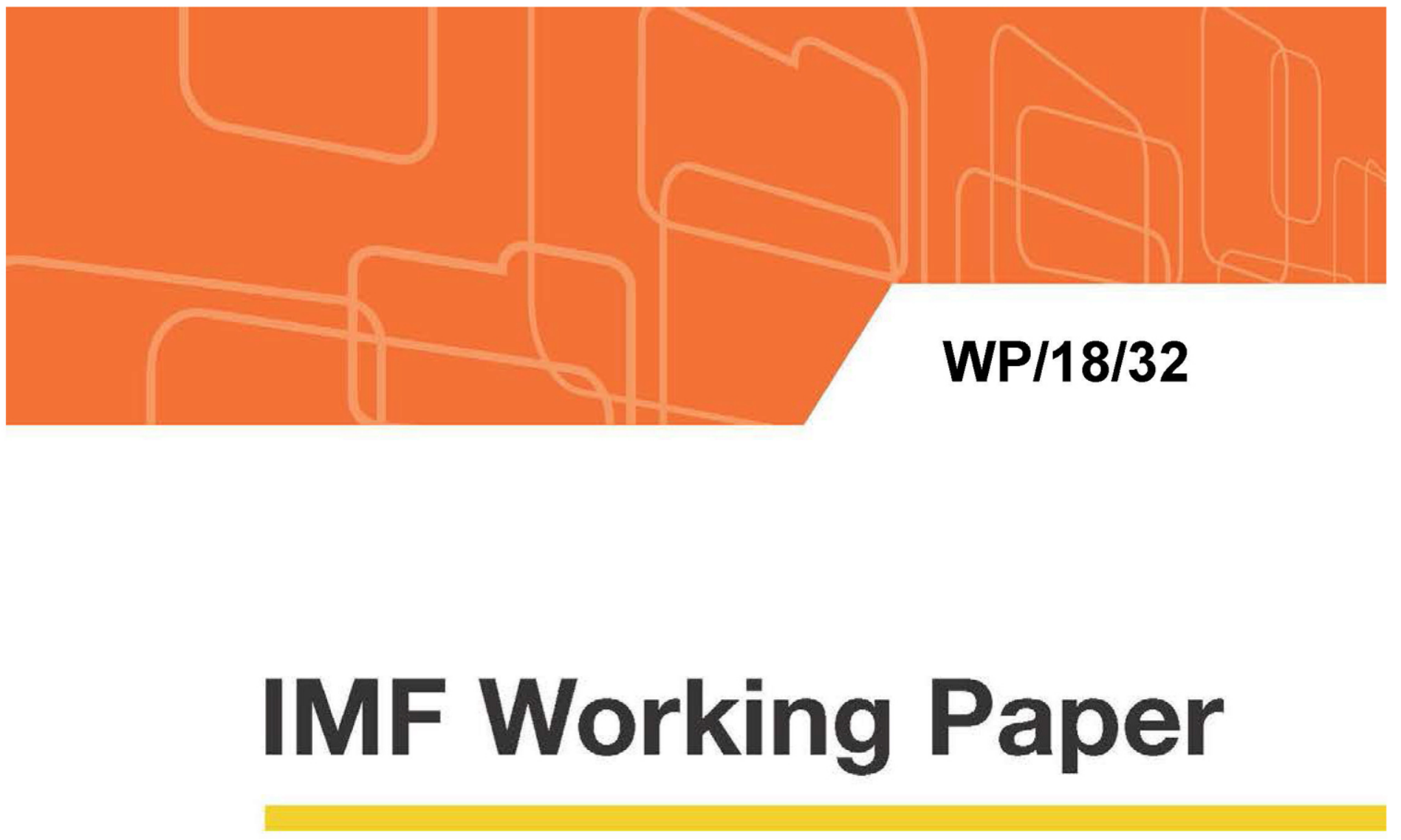

\title{
A Multidimensional Approach to Trade Policy Indicators
}

\author{
by Diego A. Cerdeiro and Rachel J. Nam
}

IMF Working Papers describe research in progress by the author(s) and are published to elicit comments and to encourage debate. The views expressed in IMF Working Papers are those of the author(s) and do not necessarily represent the views of the IMF, its Executive Board, or IMF management. 


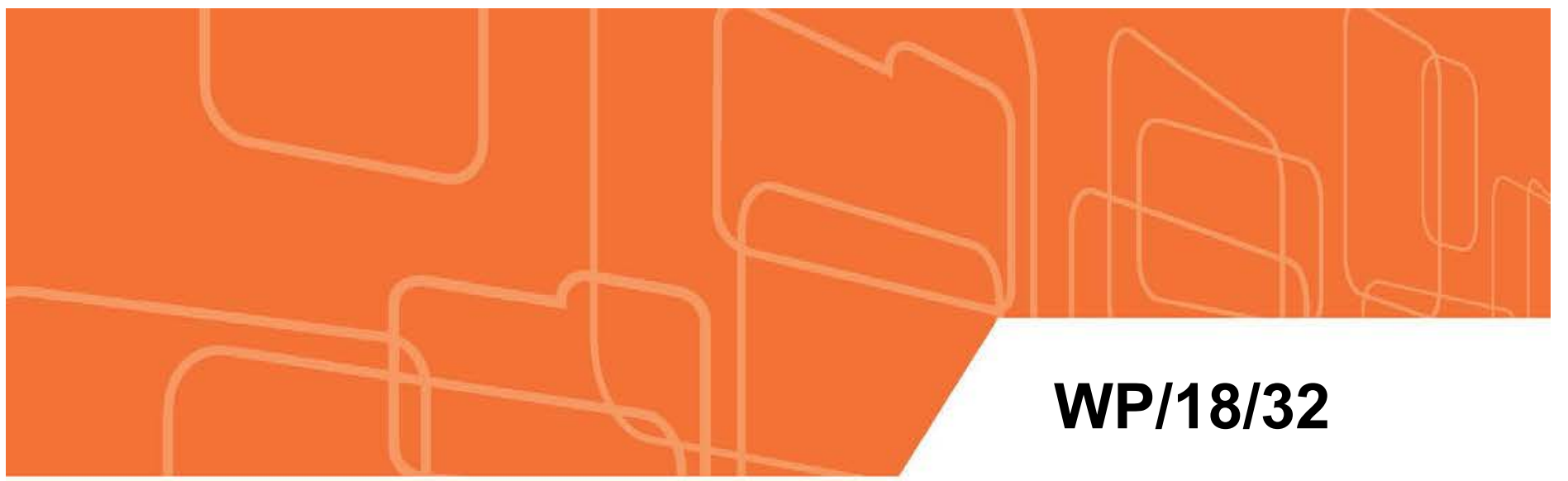

\title{
IMF Working Paper
}

\section{A Multidimensional Approach to Trade Policy Indicators}

\author{
by Diego A. Cerdeiro and Rachel J. Nam
}

IMF Working Papers describe research in progress by the author(s) and are published to elicit comments and to encourage debate. The views expressed in IMF Working Papers are those of the author(s) and do not necessarily represent the views of the IMF, its Executive Board, or IMF management.

$$
\text { I N T E R N A T I O N A L M O N E T A R Y F U N D }
$$




\title{
IMF Working Paper
}

Strategy, Policy, and Review Department

\section{A Multidimensional Approach to Trade Policy Indicators* \\ Prepared by Diego A. Cerdeiro and Rachel J. Nam}

Authorized for distribution by Martin Kaufman

February 2018

\begin{abstract}
IMF Working Papers describe research in progress by the author(s) and are published to elicit comments and to encourage debate. The views expressed in IMF Working Papers are those of the author(s) and do not necessarily represent the views of the IMF, its Executive Board, or IMF management.
\end{abstract}

\begin{abstract}
We present and discuss a set of indicators to help assess countries' trade policies. The indicators relate to three policy areas - trade in goods, trade in services, and FDI. Given concerns about the direction of global trade policy, we also consider a set of more granular measures that reflect the evolution of countries' policies since the 2008 financial crisis. We propose a simple approach to present the multidimensional aspects of trade policy that, by shedding light on relative openness across areas, can facilitate policy discussions. In the cross-section of countries, we find a diversity in the type of measures adopted, both between and (since the 2008 financial crisis) within policy areas, lending support to the approach based on multiple indicators. The indicators' time series suggest that advanced and, especially, emerging economies are moving toward more open regimes over time, although recently progress has, with some exceptions, slowed across the board. Lastly, our findings also call for stronger efforts to objectively quantify the different aspects of countries' trade regimes. More data, both across countries and in terms of policy areas that significantly affect trade, are needed for better-informed policy discussions.
\end{abstract}

Keywords: Trade policy indicators, trade in goods, services trade, foreign direct investment, trade barriers.

JEL codes: F10, F14.

Authors’ E-Mail Addresses: dcerdeiro@imf.org,jnam@imf.org

\footnotetext{
* We are indebted to Tam Bayoumi, Martin Kaufman, Brad McDonald and Elizabeth van Heuvelen for continuous discussions. We also thank, without implicating, JaeBin Ahn, Willy Alfaro, Emine Boz, Roberto Cardarelli, Nigel Chalk, Luis Cubeddu, Christian Ebeke, Anabel Gonzalez, Russell Green, Nan Li, Aaditya Mattoo, Jonathan Ostry, Peter Pedersen, Carlos Perez del Castillo, Jose Guilherme Reis, Markus Rodlauer, Michele Ruta, Christian Saborowski and various seminar participants for very helpful comments on an earlier draft of the paper. We are very grateful to Simon Evenett and Johannes Fritz for extensive interactions on the Global Trade Alert database. All errors are ours.
} 


\section{Introduction}

There is, at the current juncture, no lack of reasons underscoring the importance of trade policy on the domestic and international policy arenas. Despite advances in some areas, global trade reform has slowed down significantly since the early 2000 s, thus weighing down on trade growth (IMF, 2016a). In this context, addressing remaining trade distortions - which have fallen over time but, the evidence suggests, remain substantial - can raise productivity and growth even if there remains the complex issue of compensating losers (IMF-WTO-WB, 2017).

A generalized move to more open trade can also play a role in facilitating domestic adjustment to greater trade integration. In particular, trade barriers abroad that frustrate export expansion will prolong the domestic adjustment process for countries facing greater import competition (IMF-WTO-WB, 2017). More generally, there is also an aspiration to adopt and implement an ambitious global trade policy agenda that covers less traditional areas such as services trade. The challenge in this quest for a so-called "level playing field" across countries and sectors has been nicely summarized by Governor Carney:

"The G20 faces a choice - between levelling down by putting more restrictions on goods trade, or levelling up by liberalizing trade in services." 1

Against this backdrop, quantitative indicators that shed light on countries' trade policies can be a helpful tool to guide policy discussions. With that aim, this paper describes and discusses a set of trade policy indicators.

Barriers to trade take different forms, ranging from import tariffs, to regulatory barriers, to restrictions on services trade, and to controls on foreign investment. Because of this diversity, no single indicator can provide a complete characterization of a country's trade regime. Furthermore, these diverse barriers cannot be analyzed in isolation, as restrictions in one area may hinder any potential gains from reducing barriers in another. For example, a country with very few statutory restrictions to FDI may not be able to successfully integrate into global value chains (GVCs) if there are pervasive non-tariff barriers on goods imports.

Given that a balanced view of a country's trade policy stance requires information on different and complementary measures, the indicators described in this paper relate to three different areas of trade policy - trade in goods, trade in services, and foreign direct investment (FDI). In some cases, the indicators reflect measures that are of systemic importance, while in others the significance is higher for specific trading partners such as low-income countries. In light of concerns that the period since the 2008 financial crisis has

1 "A fine balance," speech given by Mark Carney, Governor of the Bank of England, at The Mansion House, London, June 20, 2017. 
seen an increase in different forms of protectionism despite pledges to avoid this outcome, we also discuss indicators that reflect the evolution of a more granular set of trade policies since $2008 .^{2}$

Our interest is in policies that are likely to affect trade in a significant way, and for which data are available for many countries. This implies that there are some areas that can be important but are not covered by the indicators discussed here due to data constraints. In addition to the criteria of relevance and availability, the indicators were chosen based on their relative timeliness, objectivity (nearly all are based on statutory restrictions rather than surveys), and transparency of sources and methodology. Furthermore, the indicators relate directly to policy barriers, and thus provide a better gauge of actionable policies than outcome-based measures (e.g. trade as percent of GDP, or participation in global value chains) that partly reflect countries' size, geographical location, and other non-policy factors. Having a sense of those areas of trade policy in which a particular country is more "open" or "closed" can point the way toward a useful policy dialogue. ${ }^{3}$

It is worth stressing at this point that none of the indicators described in the paper aims to benchmark countries' performance against commitments they may have, either under the WTO or vis-à-vis any other forum or agreement. For example, two countries having different average applied most-favored nation tariff rates is entirely consistent with tariffs of both countries being at or below their country-specific, WTO-agreed bound tariffs.

Additional qualitative resources can also provide information on areas that are not sufficiently covered by existing quantitative indicators. For example, behind-the-border regulatory barriers, lack of policy predictability and transparency, or overall institutional weakness, may all represent major obstacles for investment and thus for GVC participation. Complementary evidence to this end can be gathered from the in-depth analyses provided by the WTO's Trade Policy Reviews, which constitute the most detailed and comprehensive source of relevant information on countries' trade policies. The IMF's AREAER database is a useful source containing detailed descriptions on payment restrictions affecting import payments, export proceeds, and direct investment, which may also affect trade flows. In addition, country studies can also tap qualitative assessments included in WTO trade monitoring reports, including on G20 trade and investment measures, and UNCTAD or OECD investment policy reviews, and - for less developed countries - the World Bank's Diagnostic Trade Integration Studies.

\footnotetext{
${ }^{2}$ Throughout the paper, the term 2008 financial crisis refers to the 2008 North Atlantic financial crisis, as studied in detail in Bayoumi (2017).

${ }^{3}$ The approach to trade policy indicators proposed in the paper is consistent with the principles outlined in IMF (2017). The paper is transparent regarding how the indicators were selected, their underlying methodologies and data sources, and how they should be interpreted. The reliance on multiple indicators renders the analysis robust. As will become clear below, there is no single policy area where only one source is used to assess policies. Moreover, the paper points the reader to particularly valuable resources that can complement the selected indicators.
} 
The rest of the paper is organized as follows. Section 2 presents and discusses the selected trade policy indicators. Section 3 proposes a visual aid to summarize the multidimensional aspects of trade policy covered by these indicators, and discusses its application to G20 country groupings. The visual aid presented in Section 3 relies on a simple distance-to-frontier normalization. Recognizing that for countries situated at the current policy frontier in some areas this approach may not be as informative to get a sense of the scope for further liberalization, Annex II discusses an alternative normalization based on the distance to free trade. Section 4 discusses the evolution of trade policies based on the limited time series coverage of the selected indicators. Section 5 uses the selected indicators to provide evidence of the diversity of trade policy across countries. Section 6 discusses data limitations, both in terms of country coverage of available indicators, and in terms of policy areas for which no summary measure is currently available. Section 7 offers some concluding remarks.

\section{Selected trade policy indicators}

The set of indicators discussed below aims to characterize countries' overall trade policy stance. For trade in goods, they include traditional areas such as tariff protection and agricultural support, as well as non-tariff measures. With services trade comprising a quarter of global trade (and nearly half on a value-added basis), identifying restrictions to trade in services is also a key component of trade policy assessments. Lastly, the complementarity of trade and investment decisions, including due to the rise of global value chains, calls for increased attention to measures that may hamper FDI. Subsection 2.1 below will thus describe indicators on restrictions to trade in goods, services, and to FDI, as a means to shed light on relative openness across policy areas.

The paper also describes indicators that reflect the evolution of trade policies since the 2008 financial crisis. To assess the evolution of countries' trade policies since the crisis, Section 2.2 below presents indicators describing measures taken since November 2008. These measures draw on the information compiled by Global Trade Alert (GTA), which - by compiling data on various non-traditional trade barriers - is potentially able capture protectionist trends of various forms. Annex I include a table summarizing key aspects of all the indicators considered.

\subsection{Overall trade policy regime}

\section{Trade in Goods}

We use four indicators of good trade restrictiveness: 
- Simple average of applied MFN tariffs. Tariffs are arguably the most easily measurable trade cost. Yet, summarizing a country's tariff profile in a single indicator involves choices. Trade-weighted averages can overlook the effect of prohibitively high tariffs, and simple averages may assign too much weight to tariff lines with little trade even under very low tariffs. ${ }^{4}$ The simple average of tariffs has the advantage that changes over time reflect policy changes only, and not changes in a country's import structure (when the base year used for weights is not held constant over time). The two measures are, however, highly correlated in the crosssection of countries. Wherever considered relevant, the data presented here can be complemented with an analysis of trade-weighted averages; if differences are large, exploring the reasons could in some cases be of interest. ${ }^{5}$ In addition, a decision needs to be made on whether to use most-favored nation (MFN) tariffs, or account also for tariff preferences stemming from regional trade agreements. Preferential tariffs (whether through FTAs or the extension of unilateral preferences) can have a useful liberalizing effect; nonetheless, because access to preferences is conditioned on meeting certain rules of origin, the preferences are not always utilized. For simplicity and transparency, here we use the simple average of applied MFN tariffs. ${ }^{6}$ These data are available for nearly all WTO members. ${ }^{7}$

- Imports covered by non-automatic licensing. Unilateral liberalization and trade negotiations, including the conclusion of the Uruguay Round in 1995, have substantially lowered tariffs in many countries. As tariffs decreased, more attention has shifted to non-tariff measures, which broadly defined refer to any possible non-

\footnotetext{
${ }^{4}$ Annex V includes a discussion on a simple partial-equilibrium approach that has been proposed to overcome these difficulties. The approach involves using weights that incorporate tariff-line-level estimates of elasticities of substitution, as (tariff and non-tariff) restrictions on more elastic goods have, all else equal, larger effects on trade volumes. For a more general discussion on estimating trade restrictiveness, including through the use of general equilibrium approaches, see Anderson and Neary (2005).

${ }^{5}$ For example, differences can be large in the presence of very high tariffs that significantly hinder trade of some products; or if tariffs tend to be higher for higher-elasticity products, thus possibly having higher distorting effects on trade patterns.

${ }^{6}$ The term applied is in contrast to the ceiling bound rates agreed at the WTO. In many countries, especially EMDEs, there is still a large gap between bound and applied rates (also known as binding overhang). While bound rates provide a degree of predictability (Francois and Martin, 2004), a growing literature examines the detrimental effect that the possibility to raise rates in a WTO-consistent manner may have on investment and trade (see e.g. Handley, 2014; Pierce and Schott, 2016). Additional tariff-related indicators include as tariff escalation or use of special economic zones (available in WTO Trade Policy Reviews).

${ }^{7}$ Since low average tariffs may mask the presence of high tariff barriers in certain products or sectors, this information can be complemented with data on tariff peaks. Under certain conditions, a high dispersion in rates would exacerbate the negative welfare implications of tariffs (see e.g. the discussion in Costinot and RodriguezClare, 2014, Section 4.3). This result holds in theory if e.g. goods are equally substitutable, and is more likely to hold in practice if the considerations for a country's tariff profile are relatively orthogonal to products' elasticities of substitution. For a rigorous discussion of tariff dispersion and welfare, see chapters 3 and 6 in Anderson and Neary (2005). WTO World Tariff Profiles provide information on international tariff peaks, defined as the fraction of tariff lines with tariff rates over 15 percent.
} 
tariff measure that restricts trade. The Trade Analysis Information System (TRAINS) of UNCTAD systematically compiles some types of countries' non-tariff measures, grouped under 16 different categories (for a full description of the classification, see UNCTAD, 2012). For every country's tariff line, the data indicate whether a certain non-tariff measure applies. While certain non-tariff measures such as sanitary and phytosanitary standards (SPS) and technical barriers to trade (TBT) may be intended to protect consumers' health and the quality of the imported products, other (non-SPS/TBT) measures compiled in TRAINS may generally simply restrict trade. In general, the quality of data in TRAINS varies across countries. The indicator described here focuses on a specific TRAINS measure, non-automatic import licensing (TRAINS chapter E1), for which data quality is more homogeneous across countries. ${ }^{8}$ The use of non-automatic licensing can result in substantial barriers to trade, have generally detrimental effects on competition when licenses are assigned to particular traders, and induce rent-seeking behavior (Grosso, 2005). The fraction of imports covered by non-automatic licenses can provide useful evidence on the use of this type of trade-restrictive non-tariff measure. ${ }^{9}$ The calculation of import coverage is done by combining the TRAINS data with COMTRADE import data. A total of 35 countries plus the European Union have reported TRAINS Chapter E data for at least one year over 2010-2016 (over 80 percent of countries' data are from 2015).

- OECD Average Trade Facilitation Performance. Automation of import licensing is just one of various measures that countries can adopt at the border to facilitate the flow of goods trade. The formalities involved in the clearance of customs can significantly increase trade costs, potentially affecting exporters as well as importers (see e.g. Volpe Martincus et al., 2015). The Trade Facilitation Agreement (TFA) agreed by WTO members in 2013 (and in effect since early 2017) aims to address these border barriers by extending and clarifying commitments related to freedom of transit, requirements for import and export transactions, and publication and administration of domestic trade regulations. The OECD Trade Facilitation Indicators aim to quantify countries' performance under eleven different policy dimensions covered by the TFA, such as information availability, appeal procedures, fees and charges, and documentation formalities (see Section IV in ESCAP-OECD, 2017, for further details). Trade barriers covered in these different areas are estimated to significantly affect trade costs and trade flows, especially in

\footnotetext{
${ }^{8}$ TRAINS Chapter E1 measures are defined as procedures " [...] introduced, for reasons other than SPS or TBT reasons, where approval is not granted in all cases. The approval may either be granted on a discretionary basis or may require specific criteria to be met before it is granted." The assessment of homogeneity in data quality is based on consultations with experts in the field, and authors' judgement on the extent to which the import coverage of different measures adequately reflects use of non-tariff measures by different country groupings.

${ }^{9}$ The use of import coverage ratios is subject to the same caveats as average import tariffs (see footnote 2). All else equal, the requirement to apply for a license will affect trade of more easily substitutable goods relatively more.
} 
developing countries (Moïsé and Sorescu, 2013). The indicator we use here is the OECD's average trade facilitation performance, which is defined as the average across all eleven trade-facilitation dimensions and ranges from 0 (least open) to 2 (most open). ${ }^{10}$ The indicator is compiled in every odd-numbered year, and the 2017 edition used in this paper covers a total of 163 countries.

- Agricultural support, producer support equivalent. Agriculture still receives in many countries various forms of support which may distort trade directly or indirectly. Agricultural support encompasses transfers from consumers (e.g. by maintaining domestic prices above those at the border) and taxpayers (through direct transfers, or tax or credit concessions). The removal of agricultural support in some advanced economies has been estimated to unambiguously benefit developing countries that are net exporters of agricultural commodities (Hoekman et al., 2004), and could also create significant net gains for liberalizing countries (see e.g. Tokarick, 2003). The OECD produces estimates of the total value of these transfers to agricultural producers for 24 individual countries plus the European Union. ${ }^{11}$ For cross-country comparability, the indicator described here uses OECD estimates of producer support as percent of gross farm receipts (including transfers).

\section{Trade in Services}

We use two measures of restrictiveness on services trade:

- OECD Services Trade Restrictiveness Index. The growing importance of services in economic activity and trade has generally outpaced liberalization efforts (see e.g. Hoekman and Mattoo, 2013), pointing to potentially large gains from reducing existing trade barriers. The OECD produces a Services Trade Restrictiveness Index (STRI) for 44 countries and 22 different sectors. Higher services trade restrictions, as measured by the OECD STRI, have been found to be negatively associated with services imports, and can significantly affect a country's overall competitiveness in goods as well as services trade (Nordås and Rouzet, 2015). The sector-level OECD STRI indices are based on restrictions grouped under five different policy areas (for full methodological details, see Grosso et al., 2015): restrictions on foreign entry, restrictions on the movement of people, other discriminatory measures, barriers to competition, and regulatory transparency. Scores in each policy area depend on the specific sector (telecommunications, transport, courier, and financial services have

\footnotetext{
${ }^{10}$ Data by trade facilitation area can be found at www.oecd.org/trade/facilitation/indicators.htm. Details on underlying data sources, including web links to each source (such as e.g. references to relevant sections of WTO Trade Policy Reviews) can be found in Annex 2 of OECD (2012).

${ }^{11}$ As noted in the background methodological note (OECD, 2016), the estimates make no judgement on the objective of these transfers, some of which may be related for example to the presence of positive externalities. The definitions and sources used for each country can be found at the bottom of

http://www.oecd.org/agriculture/agricultural-policies/producerandconsumersupportestimatesdatabase.htm
} 
customized methodologies). The methodology is largely based on restrictions applied in practice, with the exception of the area of regulatory transparency, where some (though not all) World Bank Doing Business indicators used as input are based on surveys. ${ }^{12}$ The scoring in each area ranges from 0 (completely open) to 1 (completely closed), ${ }^{13}$ and are translated into a single indicator for each sector based on sector-specific weights for the five policy areas. These sector-specific weights are based on experts' judgement on the importance of each policy area for each sector (see Table 4 in Grosso et al., 2015). The OECD STRI is regularly updated and currently has data through $2017 .{ }^{14}$ The indicator we use is the median across all 22 sectors as an indicator of overall openness to trade in services.

- World Bank Services Trade Restrictiveness Index for exports under commercial presence. The cross-border provision of services may take different forms, depending on the location of supplier and consumer at the time of the transaction. Underscoring the complementarities between services and investment, one such form is the commercial presence of the supplier in the country of the consumer (also known as "Mode 3" in GATS terminology). Examples of such a mode of supply are, for instance, the establishment of operations for the provision of telecommunications or banking services. The World Bank Services Trade Restrictions database collects information on policies in 103 countries and 18 sectors, distinguishing among different modes of supply (see Borchert et al., 2014, for full details). Ad-valorem equivalents of the restrictions covered by the database are estimated to be above 10 percent in most sectors, in advanced economies as well as in emerging-market and developing countries (see Table 4 in Jafari and Tarr, 2017). Compared to the OECD STRI, key differences of the World Bank index are its wider country coverage, the fact that the data account for preferences in trade agreements (the OECD STRI refers to nondiscriminatory, 'MFN' policies), the data collection through publicly available sources for OECD countries and through questionnaires completed by specialized local law firms for non-OECD countries, and the fact that the reference period is 2008-2011. To measure restrictions to trade in services through commercial presence, and as a complement to the OECD STRI measure, the indicator we use is the World Bank STRI for Mode 3 trade.

\footnotetext{
${ }^{12}$ These surveys aim to elicit information on de facto (and measurable) trade costs, for which de jure information is unlikely to be available or relevant, such as the time taken between submission and acceptance of customs declarations forms.

${ }^{13}$ Benz (2017) provides estimates of ad-valorem equivalents (AVEs) of the index for six sectors, and finds that AVEs change non-linearly with increases in the index (see Figure 1 in Benz, 2017). The estimates, however, rely on the assumption that, for each sector, the country the second-lowest STRI score is completely open to services trade - an assumption that likely does not hold in practice. As a result, these estimates should be taken as a lower bound of the AVE of STRI scores.

${ }^{14}$ The information used to construct the index for each sector in each country is documented with the source and a link to the law or regulation on the corresponding OECD public website that contains the underlying data. For the background sources used in the case of a specific country X, select Country->X, Sector->All, STRI Measure->All, Variable->Answer, Comment, Source.
} 
Compared to most border barriers to trade in goods, measuring restrictions to trade in services is not as straightforward. In particular, it is worth highlighting that the two indicators on services trade restrictiveness we consider include information on behind-the-border regulations that need not de jure discriminate against foreigners. For example, regulatory discretion and lack of accountability (as when regulators are not required to provide reasons to reject a license, or there is no appeal process for foreign providers) can disproportionately affect services trade in situations that otherwise feature no explicit discrimination against foreign providers (for a discussion, see e.g. Heuser and Mattoo, 2017). The OECD and World Bank sources discussed above recognize the importance of such behind-the-border barriers in affecting services trade, and thus use them as input in the construction of their indexes.

\section{Foreign Direct Investment}

We measure restrictiveness in FDI using two indexes.

- OECD FDI regulatory restrictiveness index. FDI can not only facilitate trade in services (as illustrated in the discussion above), but also underpin trade in goods through the development of global value chains. While the traditional view has mostly seen FDI as a substitute for exports to serve foreign markets, the fragmentation of production across borders (reflected in the increasing share of intermediate input trade in total trade) implies a growing complementarity between trade and 'vertical' FDI (see e.g. Ramondo and Rodriguez-Clare, 2013, and the literature cited therein). The OECD FDI regulatory restrictiveness index, available for 62 countries (all OECD members plus 27 non-OECD members), covers statutory restrictions to foreign investment in 22 sectors. Four types of restrictions are considered: (i) foreign equity limitations, (ii) discriminatory screening or approval mechanisms, (iii) restrictions on the employment of foreigners as key personnel, and (iv) other operational restrictions, e.g. restrictions on branching and on capital repatriation or on land ownership by foreign-owned enterprises. Restrictions are evaluated on a 0 (open) to 1 (closed) scale, with the overall restrictiveness in each sector being a weighted average of the scores in each category. FDI reforms captured by the index in many cases precede significant increases in FDI inflows (see e.g. Nicolas et al., 2013, and Figure 3 in OECD, 2017). The information on which the index is based is updated annually and currently available through 2016, and is gathered through notifications for countries that adhere to the OECD Declaration on International Investment and Multinational Enterprises, and through OECD Investment Policy Reviews for other countries, with information updated on a yearly basis following the OECD Freedom of 
Investment monitoring of investment measures (see e.g. Box 1 in OECD, 2017, for further background). ${ }^{15}$

- World Bank-IFC starting a foreign business, ease of establishment index. To complement the OECD FDI index, we use the World Bank-IFC starting a foreign business-ease of establishment index. This index collects information on restrictions to start a foreign business, including for example those on the composition of board of directors and appointment of managers, use of a local third party during the establishment process, and requirements for investment approval. ${ }^{16}$ The scores are based on surveys completed by lawyers, professional service providers (e.g. accountants), investment promotion institutions, chambers of commerce, law professors, and other expert respondents in the countries covered. All questions in the survey receive an equal weight, and the results are normalized from 0 (most restrictive) to 100 (least restrictive). Respondents are asked to submit answers on the basis of a hypothetical foreign company that meets certain criteria (e.g. it is wholly foreign-owned, it is the parent company's first investment in the host country, and plans to sell manufactures locally as well as export them). This indicator has the advantage of having a slightly broader country coverage (87 countries) than the OECD FDI regulatory restrictiveness index. By being questionnaire-based, the index may detect de facto restrictions that are not fully captured by the OECD FDI regulatory restrictiveness index (which is based on statutory, or de jure barriers). As in the case of the World Bank index for services restrictions, this indicator is relatively more dated - the latest available update of the indicator corresponds to 2012 .

\subsection{Trade and trade-related policies adopted since the 2008 financial crisis}

Global Trade Alert (GTA), a Centre for Economic Policy Research initiative based at the University of St. Gallen, is a comprehensive database for all types of trade-related measures imposed since the 2008 financial crisis, with the barriers included in the database being negatively associated with real import growth (IMF, 2016a). GTA data are compiled by an independent team of trade policy analysts located around the world, and cover measures taken since November 2008 that are likely to affect the relative treatment of domestic vis-àvis foreign competitors. ${ }^{17}$ Inclusion of a measure in the GTA database does not indicate that

\footnotetext{
${ }^{15}$ The reports produced by the OECD Freedom of Investment Process are publicly available at the bottom of the following website: http://www.oecd.org/investment/investment-policy/g20.htm

${ }^{16}$ For full methodological details, see http://iab.worldbank.org/Methodology/starting-a-foreignbusiness\#establishment

${ }^{17}$ Here we refer exclusively to what GTA labels red measures, i.e. measures that have been implemented and almost certainly discriminate against foreign commercial interests. GTA requires five other conditions to be met in order for a red measure to enter the database. The database accounts both for trade-restricting and trade-
} 
the measure is WTO-inconsistent or that it is subject to legal challenge. Measures are only published in the GTA database after a two-step review process by trade experts, and wherever possible official sources are used to document government actions. Data are available for about 170 countries, although it is possible that restrictions enacted by smaller, less-visible countries are under-detected and thus underrepresented.

This paper uses six different types of measures in the GTA database. The data correspond to the share of trade covered by the measures, except in the case of FDI measures, where the number of measures is used. ${ }^{18}$ Trade shares are calculated using trade values of a base period (2005-2007). The measures considered are:

- Import duties and taxation. Included in this category are import tariffs, and internal taxation of imports.

- Non-tariff import restrictions. These measures include import licensing requirements, quotas, bans, and tariff quotas.

- Export-restrictive measures. Export restrictions drive a wedge between domestic and international prices of the restricted products. By depressing domestic prices of the restricted products, targeted export restrictions can provide an advantage to exporters whose exports are unrestricted. For example, an export ban on a certain primary product that is used as input in the production of exported manufactures gives the exporter an advantage over international competitors. GTA measures included in this category are bans, tariff quotas, quotas, licensing requirements, taxes, and exportrelated non-tariff measures nes.

- Localization requirements. Localization requirements refer to measures that force or incentivize the use of domestic inputs or factors of production. Measures included under this grouping include those on sourcing, operations, labor, and localization incentives.

liberalizing measures. The handbook containing the GTA methodology can be found at http://www.globaltradealert.org/data extraction

18 The full list of measures of any country, with links to original sources, can be found at http://www.globaltradealert.org/countries. The World Bank's temporary trade barriers database offers an alternative, complementary source for trade defense measures. The World Bank database covers fewer countries and is less-frequently updated than the GTA database. The WTO Trade Monitoring Database provides references to background documentation on trade-restricting and trade-liberalizing measures related to tariffs, taxes, custom procedures, quantitative restrictions, and other measures. Classification of measures into traderestricting and trade-liberalizing, and into those still in place and those that have been lifted, is not systematic. As mentioned in the introduction, the IMF's AREAER database is a useful source describing payment restrictions affecting import payments (classification VII), export proceeds (VIII), and direct investment (XI.A.5). As with the Trade Monitoring database, it is not designed to track policy changes over time. 
- FDI measures. FDI measures in GTA include those on entry and ownership, treatment and operations (including also e.g. taxes on foreign assets that may restrict outward investment), and financial incentives.

- Trade defense measures. These include antidumping, countervailing measures, and safeguards. Inclusion of trade defense measures only indicates that the measure has been taken, and does not involve an assessment of whether the measure is consistent with WTO rules on trade defense measures nor whether the measure is an appropriate response to actions by foreign exporters or their governments.

\section{Assessing trade policy based on the indicators: A visual aid}

An overall diagnostic of a country's trade and investment policies using the indicators described in the previous section must overcome two separate challenges. First, the fact that the different indicators are not expressed in comparable units of measure (e.g. tariffs are advalorem, non-automatic licensing is measured through import coverage, and the OECD STRI is an index ranging from 0 to 1 ). To address this issue, we normalize every indicator with respect to a reference set of countries (G20 members in this paper), where 0 corresponds to the country that is least open and 1 to the country that is most open for that indicator. While this makes the assessment relative rather than absolute (e.g. it is likely that the most open country may still be able to pursue further liberalization), it has the advantage of allowing for some degree of comparability across different policy dimensions. It is important to bear in mind, however, that the comparability across different policy dimensions that this normalization allows is only in a distance-to-frontier sense. In fact, by discussing an alternative normalization where a score of 1 is assigned to free trade, Annex II shows that further trade liberalization is possible across most areas, including for countries at the current frontier. More generally, any normalization is bound to have limitations, underscoring the importance of also taking into account the non-normalized indicators as well as qualitative data sources. The second challenge relates to how to summarize the data in a meaningful way, i.e. without any loss of valuable information provided by each indicator. To this end, here we rely on spider charts that depict all normalized policy indicators.

Figure 1 illustrates how the various policy dimensions can be summarized with spider diagrams to arrive at an overall picture of countries' trade and investment policies. The example relies on data for individual G20 members, and compares, for each indicator, the overall G20 average with the G20 advanced-economy and G20 emerging-market averages (see Annex III for the underlying country-level data). There are at least two salient features in the chart that are worth highlighting. First, that even though the dominant types of distortions vary across countries, G20 advanced economies appear generally more open (on average) than their emerging-market counterparts. Although we should not necessarily expect emerging market countries to be as open as advanced economies, which began to open to trade much earlier, in this context, it is worth noting that EMs have liberalized faster over the last two decades, particularly from the mid-1990s to the mid-2000s (see Section 4 below). 
The exception to the current configuration is the level of agricultural support, which remains relatively large in some advanced economies - an area that is particularly significant for some trade partners. Second, that the gap between advanced economies and emerging market economies is particularly pronounced for the OECD services trade restrictiveness index as well as in terms of trade facilitation. This lends partial support to the view, discussed in the introduction, that liberalization efforts have been somewhat asymmetric not just across countries, but also across sectors. ${ }^{19}$

While averages by country grouping mask somewhat large heterogeneity, emerging market G20 members also appear to have adopted more trade-restricting measures since the 2008 financial crisis when measured through trade coverage ratios (and, in the case of FDI measures, through the number of measures) (Figure 1, right-hand-side panel). As noted, however, within-group heterogeneity is in some cases large. For example, the import coverage ratio of import duties and taxation among emerging market G20 members ranges from about 2 percent in the most open country to over 30 percent in the least open one (see Annex III for details).

\footnotetext{
${ }^{19}$ We note, however, that the gap between country groupings is not as pronounced for services exports under commercial presence (as measured by the World Bank index).
} 
Figure 1. Selected Trade Policy Indicators - Example with G20 Member Countries

$(0=$ least open country in $\mathrm{G} 20 ; 1=$ most open country in G20)
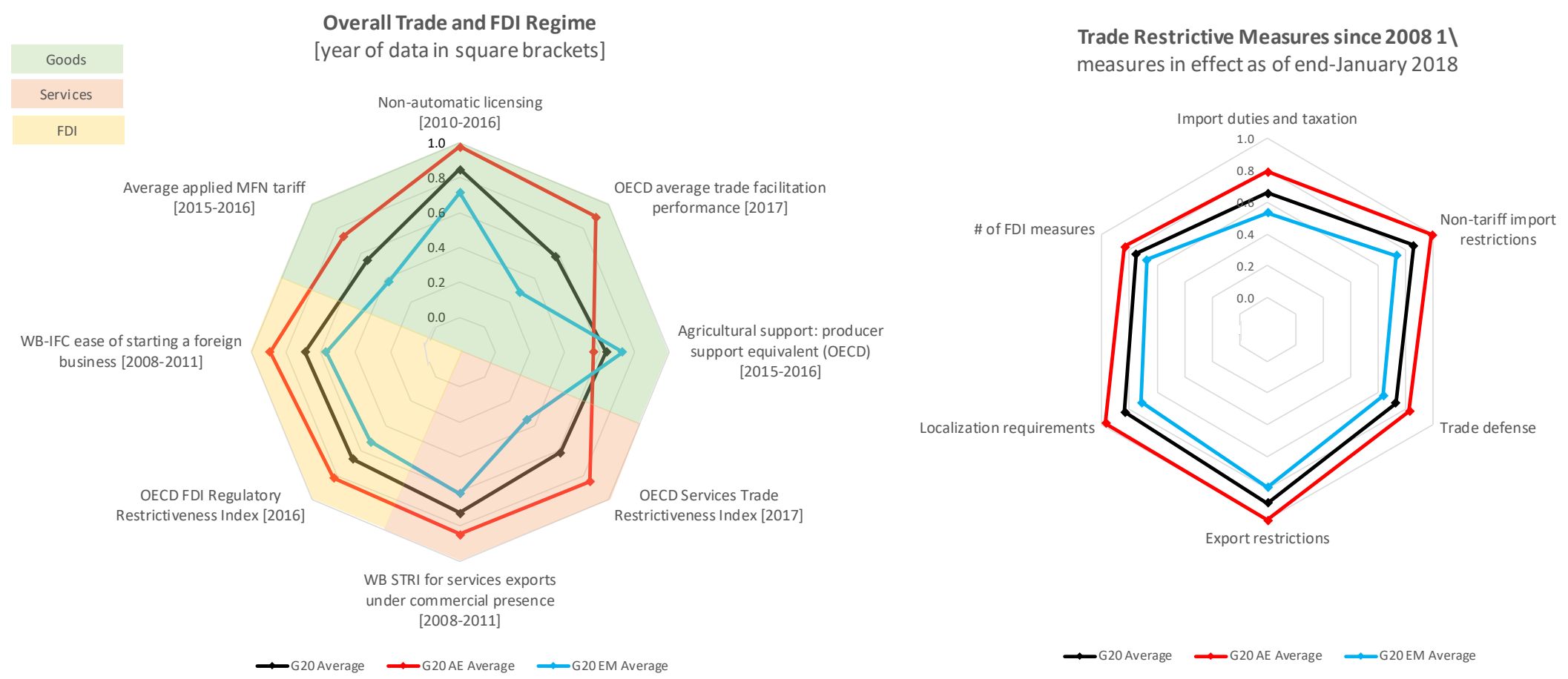

Notes: The indicators reflect no judgment as to WTO compliance of underlying measures, nor whether certain measures (such as trade defense) are an appropriate response to the actions of other countries. The "ease of starting a business" indicator is based on perceptions as part of an established IFC survey process.

Sources: Tariff data are from the WTO, World Tariff Profiles; the import licensing measure is based on UNCTAD TRAINS and COMTRADE data; the average trade facilitation performance, agricultural support measure, Services Trade Restrictiveness Index (STRI), and FDI Restrictiveness Index are from the OECD; WB STRI is from the World Bank; the post-GFC indicators are from Global Trade Alert.

$1 \backslash$ Import (export) coverage ratio, except for the case of FDI (number of measures). 


\section{On the evolution of trade regimes}

Figure 1 is a useful visual aid to summarize the current configuration of trade policy regimes. Time series data are also available for some of the indicators used to characterize countries' overall trade regime. While the time series coverage is very limited, a look at these data can be useful to uncover some trends in trade regimes. In the cases of the indicators on trade facilitation and OECD services restrictiveness, only very recent data are available. Data on tariffs, agricultural support, and FDI regulatory restrictiveness go back to the mid-1990s.

Figure 2 shows, by country grouping, the evolution over time of these five overall-traderegime indicators for which at least some time series data are available. Various stylized facts emerge from this picture. First, in the three indexes with longer time series, emerging market countries as a group made significant strides toward less restrictive policies, as reflected in the significant declines in average tariffs and the level of FDI restrictiveness. While advanced economies also became more open over this longer period, the differential reduction in barriers in emerging market countries suggests convergence toward more open regimes over the longer horizon.

When focusing on the evolution of policies in the last decade or so, however, the indicators largely reflect that reforms have slowed across the board (see also, e.g., IMF, 2016b). Further tariff reductions have been limited; agricultural support remains high in advanced economies, and appears to have recently increased in emerging markets; barriers to FDI have, on average, changed little in emerging markets; and services trade remains a frontier area that still needs to be tackled everywhere. As shown by the right-hand-side panel of Figure 1, the lack of progress on these fronts is compounded by various trade-restrictive measures taken by both advanced and emerging economies. A notable exception to these developments is the area of trade facilitation, where a lot of progress appears to have been achieved in a very short period of time, perhaps underscoring the value of agreements with multi-speed implementation and implementation assistance such as the Trade Facilitation Agreement. 
Figure 2a. The evolution of trade policies since the mid-1990s

Average applied MFN tariffs (\%)

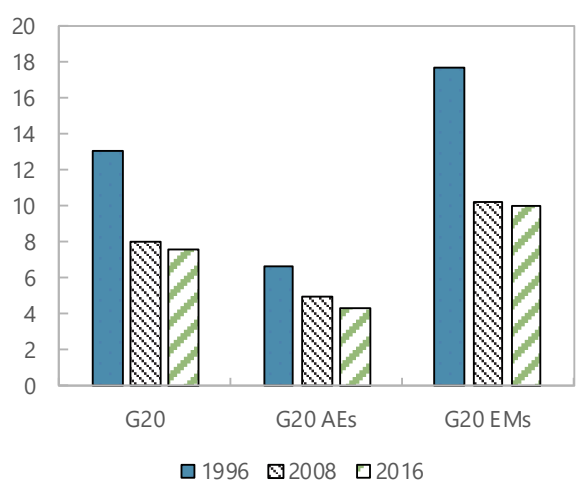

OECD FDI Regulatory Restrictiveness

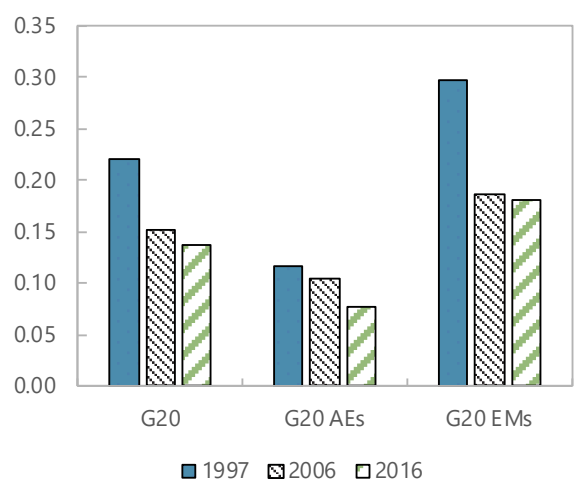

Agricultural support (\%)

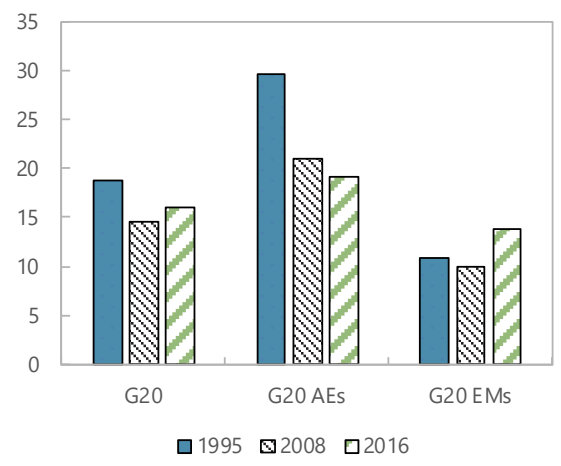

Figure 2b. Recent evolution of trade policies
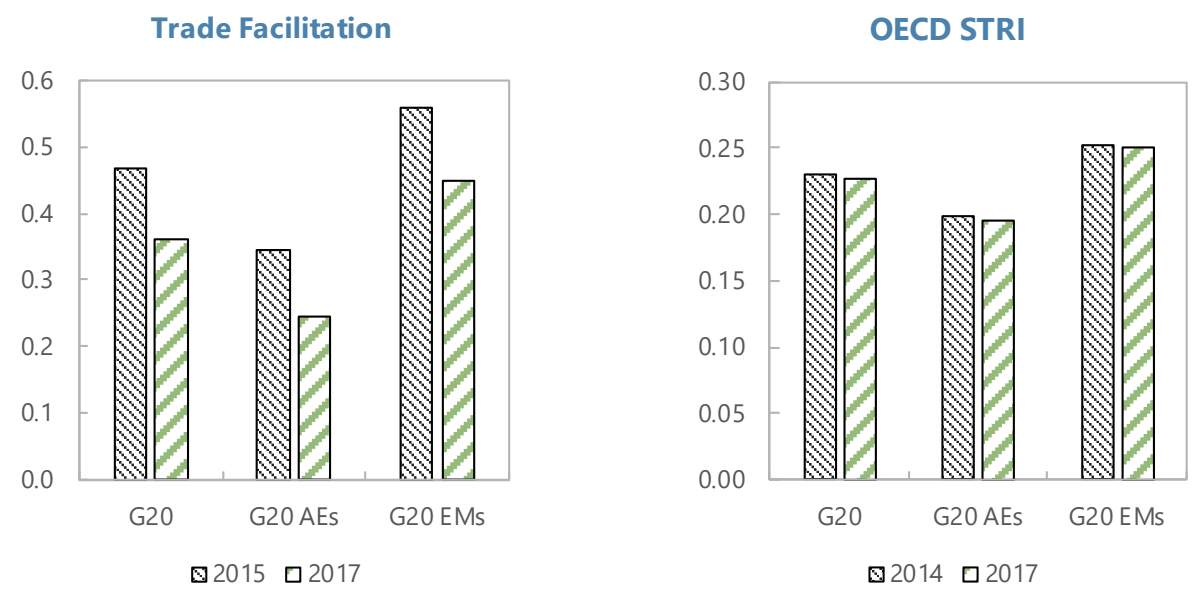

Sources and notes: WTO, OECD, and authors' calculations. All indicators presented in raw form, except the OECD's average trade facilitation performance, which is re-normalized so that lower values also correspond to less-restrictive regimes. 


\section{The diversity of trade policy}

As mentioned from the outset, it would be difficult - if at all possible - for a single indicator to provide a comprehensive assessment of countries' policy barriers to trade. To assess the benefits of our multidimensional assessment of trade policy, Figure 3 shows the correlations matrix between all selected indicators for G20 countries. The matrix in the top panel is arranged so that indicators pertaining to a given trade policy area (goods, services, FDI) are grouped together.

Various messages arise from this overall picture. First, that correlations within policy area for indicators depicting the overall regime (i.e. the indicators used for the LHS panel of Figure 1) tend to be high. We believe this can provide robustness to assessments that use these indicators. For example, correlations are high between average tariffs and nonautomatic licensing coverage ratios, and between services and FDI indicators. An exception to this is the case of agricultural support, which is particularly high in advanced economies that have otherwise significantly reduced other barriers to goods trade. Second, it is worth pointing out that correlations between different policy areas is not always high. In particular, while policy barriers to trade in services appear highly correlated to FDI restrictions, it is much less clear whether countries' resort to restrictions to trade in goods is associated with barriers related to services and investment.

Countries' preferences for different policy tools is also marked in the varied restrictions to goods trade adopted since the 2008 financial crisis (as measured by their trade coverage ratios; bottom panel in Figure 3). There appears to be a relatively high correlation between the use of import duties and taxation, trade defense, and FDI measures, as well as between export and non-tariff import restrictions. Correlations, however, are not always high. For example, the imposition of import duties and taxation since the crisis has been virtually orthogonal to the adoption of non-tariff import restrictions.

This diversity in trade policy - both between areas, and in the different measures adopted since the crisis - underscores the information value of different indicators, and thus the benefits of our multidimensional approach. 


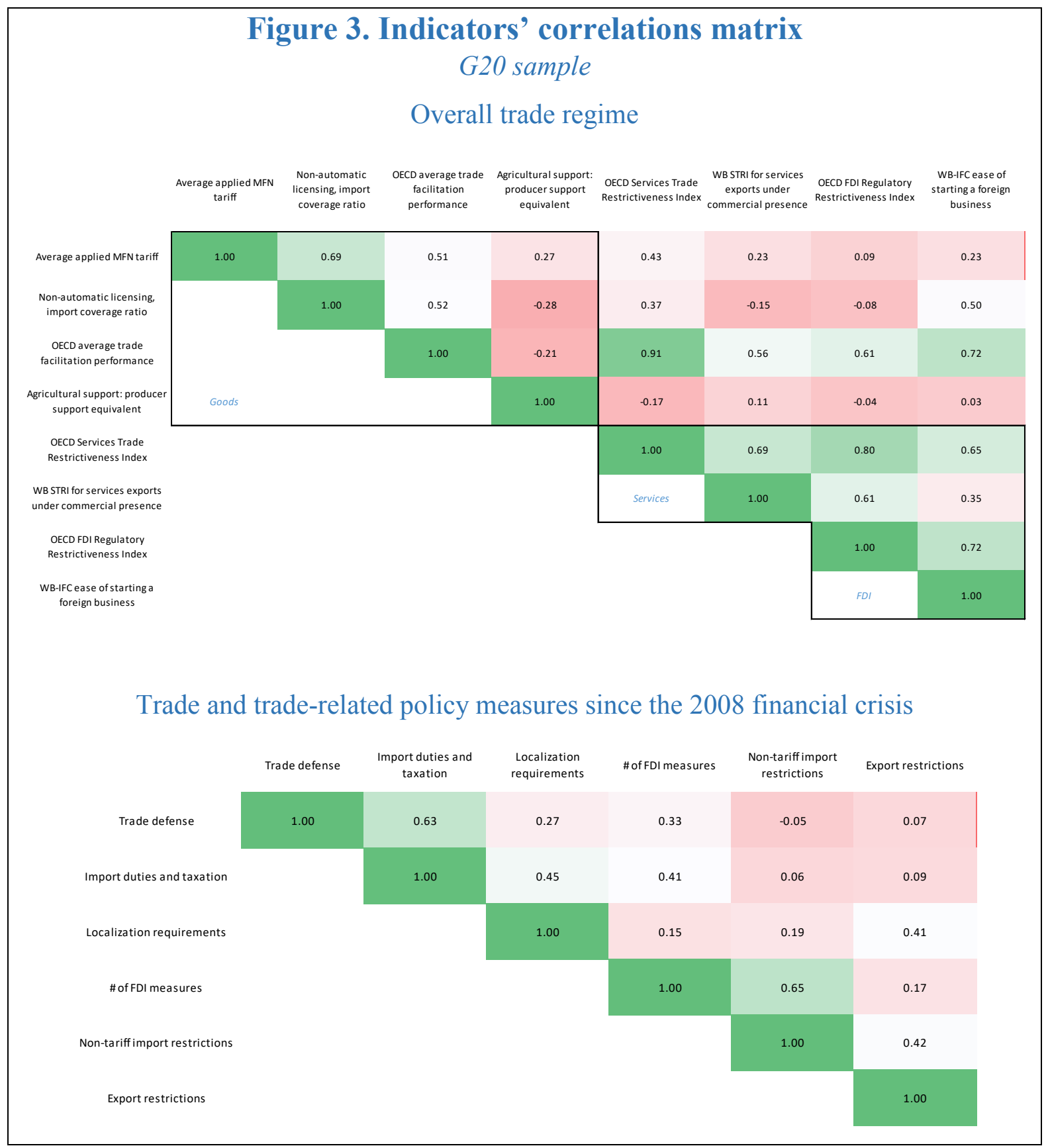




\section{Data gaps}

Data gaps are, unfortunately, an important limitation for any analysis of countries' trade policies. In this section, we discuss the limited country coverage for the indicators used above, and point to important policy areas for which, to the best of our knowledge, no comprehensive summary measure is available.

\subsection{Country coverage of selected indicators}

In this section we focus on the coverage of those indicators used to describe countries' overall trade regime. The two dimensions of interest are (i) the number of countries with available data for each indicator, and (ii) the number of indicators available for each country. ${ }^{20}$ Figure 4 shows the number of countries covered by each indicator. The three indicators produced by the OECD (the OECD STRI, the estimate of agricultural support, and the FDI regulatory restrictiveness index) have the narrowest coverage; data are available for between 44 and 63 countries only. In the case of non-automatic licensing, we have restricted our attention to those countries that have reported TRAINS Chapter E data at least once between 2010 and 2016. The result is a group of 35 countries plus the EU, i.e. a set covering 63 countries (over 80 percent reporting data for 2015). Data coverage improves with the two World-Bank based indicators (ease of starting a foreign business, and STRI for services under commercial presence). The widest country coverage is, naturally, for WTO-compiled tariff data, reaching 167 countries.

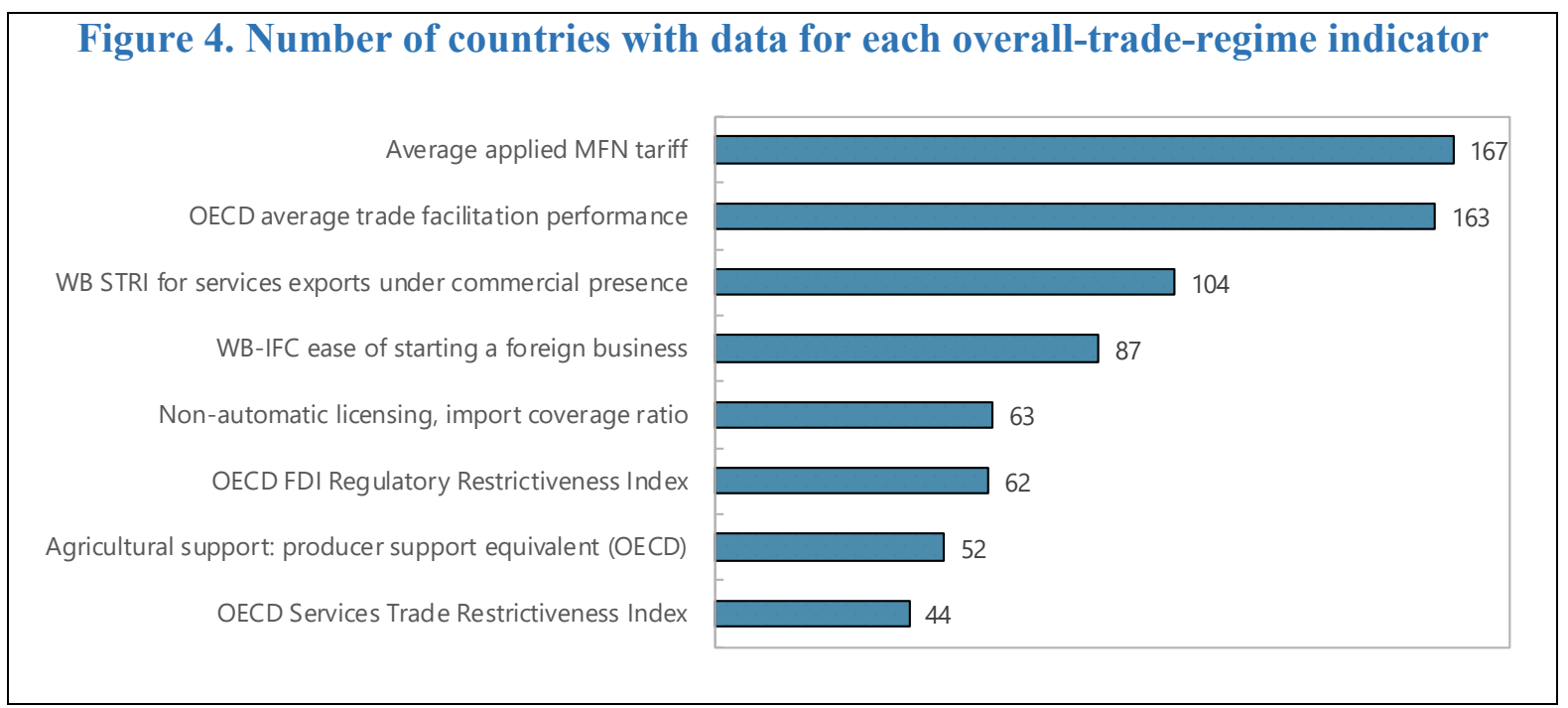

\footnotetext{
${ }^{20}$ Global Trade Alert, which is the source for the indicators describing the evolution of policies since the 2008 financial crisis, has in principle data for all countries in the world (although in practice many measures adopted by smaller and less visible countries may go undetected).
} 
Figure 5, where countries' shading intensity is proportional to the number of indicators available, shows the geographic distribution of these data gaps. Perhaps unsurprisingly, data scarcity is most severe in Africa and the Middle East. There is in fact a total of 15 countries for which not even tariff data are available (see Annex IV for country-level details). Data are also somewhat scarce for Latin America and parts of Europe and Asia. The general problem of data gaps, however, goes beyond EMDEs. The extent to which most analyses of countries' trade policies will partly be bound by data constraints is perhaps best exemplified by the fact that only 20 countries have data for all eight overall-trade-regime indicators (see Annex IV).

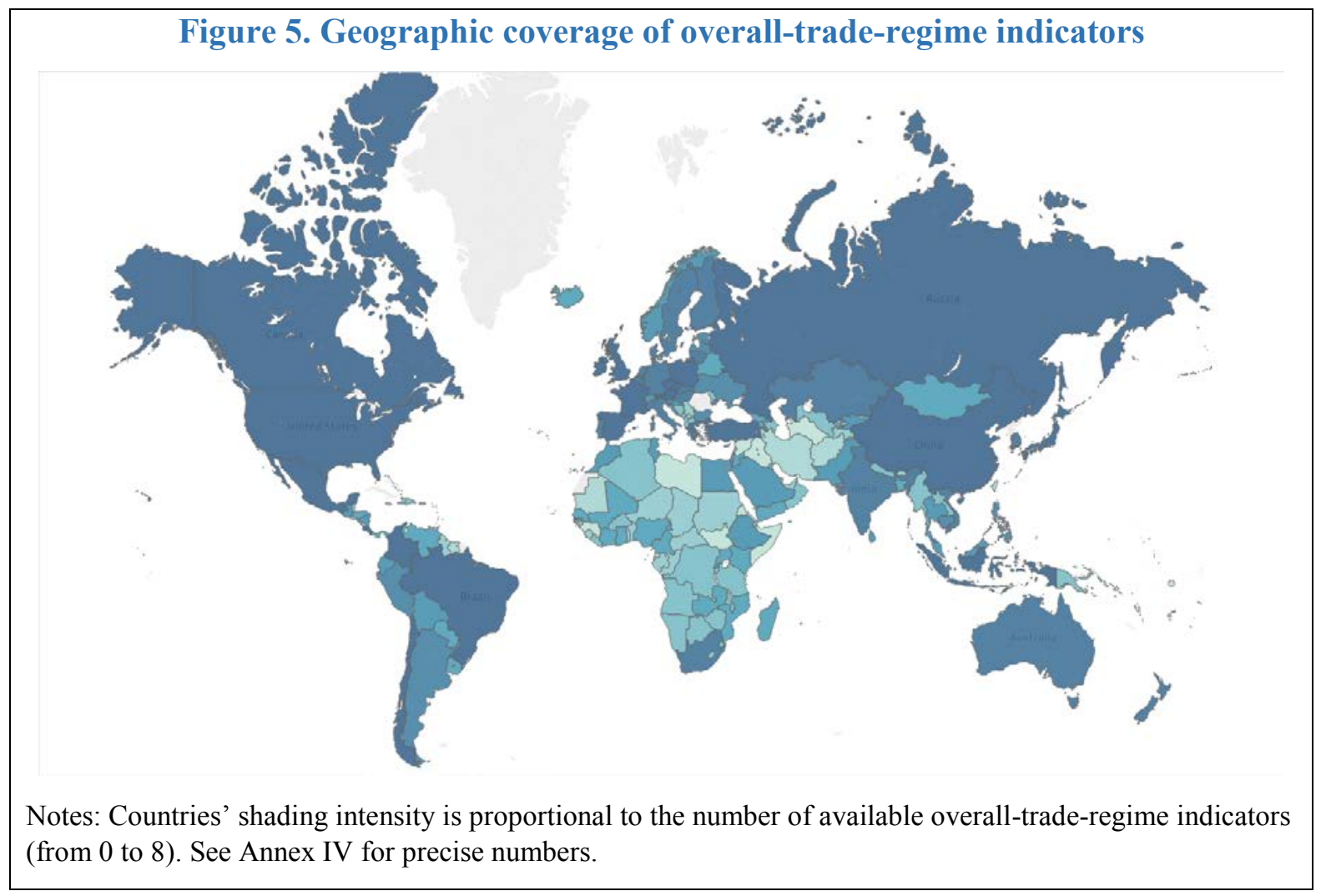

\subsection{Important policy areas not covered by selected indicators}

This subsection briefly discusses four important trade-related policy areas - standards, subsidies, government procurement, and intellectual property - for which comprehensive cross-country measures of the degree of restrictiveness are not available. The fact that quantitative information is more elusive in these areas reinforces the importance of consulting other qualitative sources, as well as the indicators presented in this paper. 


\section{Standards and regulations}

The reduction in traditional trade barriers (tariffs, quotas, etc.) in most advanced economies has shifted more attention to standards and other regulatory barriers, both at the border and behind it. For example, multiple and overlapping certification procedures can stifle competition, sometimes without positive effects on the safety of products and services for consumers. Regulatory diversity across countries and regions has led negotiators to start to bring regulatory cooperation issues into trade agreements (IMF, 2016b). Around 60 percent of preferential trade agreements contain provisions on sanitary and phytosanitary standards and technical barriers to trade (WTO, 2011), with some agreements already including legally-enforceable harmonization of consumer protection regulations (see e.g. Hofmann et al., 2017). ${ }^{21}$

Despite the area's growing importance in trade policy discussions, data are still scarce. The lack of summary measures on standards and regulations has in fact led some researchers to rely on case studies to highlight their importance for trade (see e.g. Bown and Crawley, 2016). The task of creating such summary measures is, to some extent, complicated due to the challenge of detecting regulations that simply intend to limit competition, or do so with another objective (e.g. the protection of consumers, workers, or the environment) that can be achieved under commonly-agreed, mutually-recognized or mutually-enforced standards. In some cases - especially in EMDEs - these difficulties are compounded by transparency issues, as simply making easily available to foreigners the relevant information on regulatory requirements can foster competition. More empirical work in this area is needed to inform current policy discussions. ${ }^{22}$

\section{Subsidies}

Acknowledging the trade-distorting effects of subsidies, including their excess capacity implications in some industrial sectors, at their meeting in Hamburg in 2017 G20 leaders made a call "for the removal of market-distorting subsidies and other types of support by governments and related entities." Available information on subsidies from official sources

\footnotetext{
${ }^{21}$ It is worth noting that WTO rules already include meaningful provisions. For example, the Technical Barriers to Trade (TBT) agreement obliges members to ensure that standards do not create unnecessary obstacles to trade, and provides a code of good practice that encourages, inter alia, the adoption of international standards (see the WTO ISO Standards Gateway for the list of governmental bodies that have accepted this code).

${ }^{22}$ Binary data on whether, for a given tariff line and trade partner, an SPS or a TBT is in place can be found in the UNCTAD TRAINS database. It is likely that many, if not most, measures in this database increase the quality of the product. For a discussion of academic literature on the effect of standards on trade, including the of the impact of mutual recognition and harmonization agreements, see Ederington and Ruta (2016). Reis and Farole (2011, pp. 170-193) discuss some alternatives measures of trade-related aspects of standards, such as ISO certification rates.
} 
for a large number of countries is, however, very limited. ${ }^{23}$ While WTO agreements stipulate that members must notify the WTO of subsidies that have trade effects, ${ }^{24}$ commitments have been mired by "chronic low compliance" (WTO, 2017). To give a sense of the scale of the problem, as of April 2017 nearly half of all WTO members had not yet complied with their obligation to submit notifications by June 30, 2015 (Figure 6). Reflecting these data gaps, one of the objectives of the Global Forum on steel capacity (mandated by the G20 2016 Hangzhou summit) is to increase and enhance information sharing between governments. In this context, wider official data coverage, in terms of both countries and sectors, remains essential for better-informed policy discussions. ${ }^{25}$

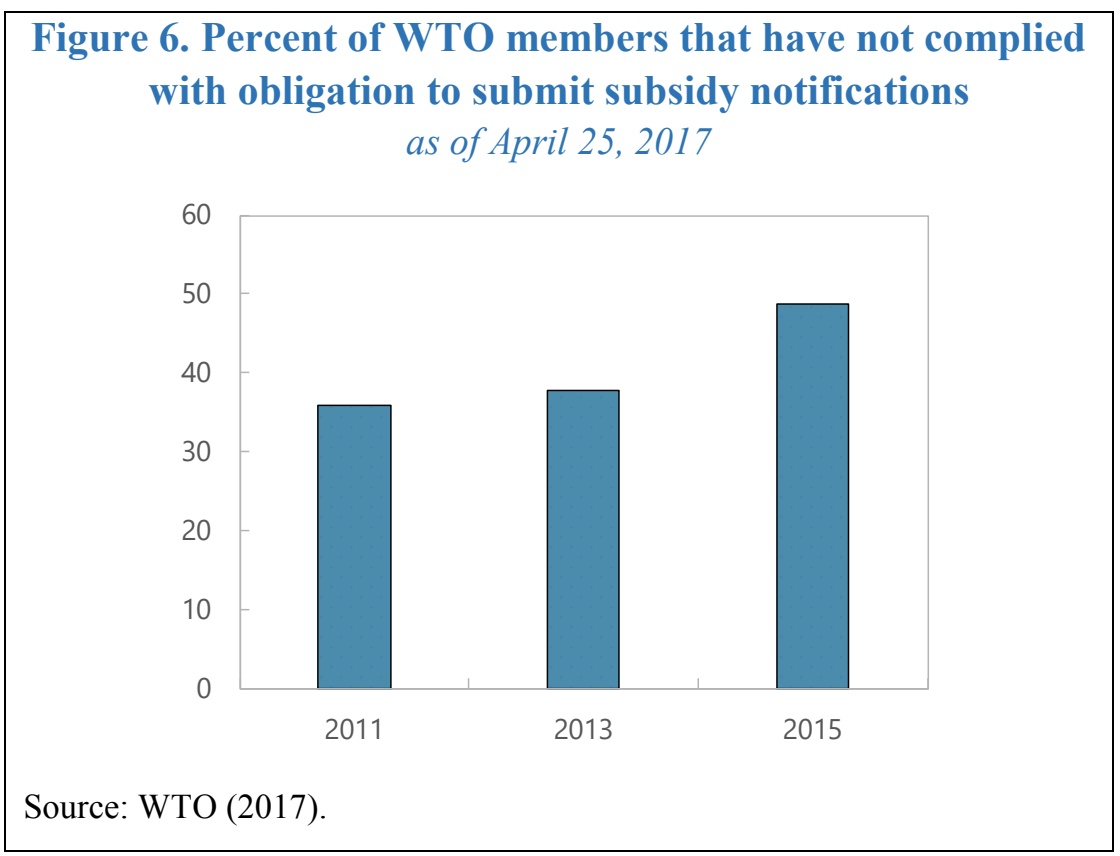

\footnotetext{
${ }^{23}$ As seen in the previous subsection, even in the case of agricultural subsidies (which is covered by the OECD estimate of agricultural support) country coverage is relatively limited.

${ }^{24}$ Members must notify any specific subsidy (i.e. a subsidy available only to an enterprise, industry, group of enterprises, or group of industries in the jurisdiction that gives the subsidy), and any subsidy (specific or not) that directly or indirectly causes trade effects (Agreement on Subsidies and Countervailing Duties (ASCM), Art. 25.3; and GATT, Art. XVI.1). Members must submit new and full notifications by June 30 of every oddnumbered year (WTO, 2013, Section 2.1). Notifications of specific subsidies should include the form of the subsidy (grant, loan, tax concession, etc.), the total amount and (if possible) the subsidy per unit, the purpose of the subsidy, its time limits, and statistical data that would allow to assess the trade effects (ASCM, Art. 25.3).

${ }^{25}$ Global Trade Alert's database can be a useful non-official source of information on subsidies implemented since November 2008. At the moment, the database does not provide systematic information on subsidy amounts (for direct subsidies and tax breaks), and subsidy components (important e.g. for trade finance measures). Complemented with specific country knowledge, however, the data can potentially be very useful in country-level studies.
} 


\section{Government procurement}

Government procurement accounts for a significant fraction of global final demand. Procurement is estimated to represent, on average, over 10 percent of GDP across different country income groupings, from low-income countries to advanced economies (Djankov et al., 2016). WTO Trade Policy Reviews contain detailed information on countries' government procurement policies, and even a cursory look at the evidence provided in these reviews reveals that discrimination in procurement is generally stark and widespread (see e.g. Evenett and Hoekman, 2004). There is, however, no data source that systematically compiles the degree of discrimination (either de jure or de facto) in procurement practices for a broad set of countries, and systematic data comparisons are difficult even for the case of countries that submit data in the context of the WTO's Government Procurement Agreement (Anderson et al., 2011; European Union, 2017). ${ }^{26}$ Better and more comparable data on the extent of discrimination in government procurement are required to complement the existing indicators on countries' overall openness to trade in goods and services.

\section{Intellectual property}

Deemed an important determinant of trade and FDI, intellectual property (IP) rights were explicitly incorporated into the Uruguay negotiations round, and resulted in the agreement on Trade-Related Aspects of Intellectual Property Rights (TRIPS). Detailed qualitative information on IP rights frameworks for WTO members can be found in Trade Policy Reviews, while countries commitments under preferential agreements have been coded in recent databases (Dür et al., 2014, Hofmann et al., 2017). Quantitatively summarizing the overall extent of IP rights protection across countries, however, would need to address various challenges. Differences between de jure protection and the enforcement of such protection can in principle be large. Fully accounting for de facto IP protection would, in turn, require survey-based approaches that can be subject to systematic perception biases across countries. Besides these positive challenges, it is far less clear than in other policy areas how to make normative assessments. Stronger IP rights can be beneficial to advanced economies and even a binding constraint for growth in emerging market countries that seek to expand R\&D capabilities (see e.g. Ang et al., 2014), but may in some cases be detrimental to welfare in low-income countries (Helpman, 1993). Even in advanced economies, IP protection needs to balance incentives to innovate with behavior aimed at capturing

\footnotetext{
${ }^{26}$ The Global Procurement Agreement's website contains valuable information on the agreement and countries' commitments. The OECD regularly produces public procurement reviews, including for specific country agencies. The World Bank's Benchmarking Public Procurement report contains valuable information about countries' procurement practices, although it does not address discriminatory treatment of foreign firms. As in the case of subsidies, Global Trade Alert's database provides useful information on discriminatory government procurement measures implemented since November 2008. Given that the pre-crisis 'stock' of restrictions on government procurement is likely very large, a comprehensive assessment of the extent of discrimination requires information on the overall government procurement framework, including those laws and regulations adopted before 2008 .
} 
monopoly rents.

\section{Concluding remarks}

In a context of increasing importance of trade in policy discussions, we have aimed to present and discuss a set of indicators that, taken together, should form a useful additional input for the assessment of countries' trade regimes. The diversity in the type of barriers across countries, both between and (since the 2008 financial crisis) within policy areas (i.e. goods, services, and FDI), suggests that the approach based on multiple indicators is useful and warranted. Because of the limitations inherent to any summary indicator, and given the lack of quantitative information for some important policy areas, these indicators are best used in conjunction with qualitative sources, including for example WTO Trade Policy Reviews. Information about countries' specific context is also essential for discussions about the scope, sequencing and pace of trade reforms (IMF, 2010).

There are various avenues for future work that would help to further improve the ability to make trade policy assessments. In an effort to draw attention to specific policies rather than the indicators themselves, we have deliberately eschewed the problem of creating summary measures of openness to trade. Such summary measures may be useful in some contexts, and the trade literature offers various approaches that may be pursued in future work (e.g. as in the work on some goods-trade barriers by Anderson and Neary, 2003; see also discussion in Annex V). To complement the distance-to-policy-frontier comparisons used in this paper, it would be particularly useful to develop approaches that link the existing trade policy indicators to ad valorem equivalents and trade outcomes. A better understanding of the broader gains from reducing one or (given likely complementarities) various barriers would require empirical work that connects these quantitative indicators to productivity and living standards. As is clear from our discussions in Section 6, however, such exercises would require clever approaches to sort data challenges. If anything, our findings call for stronger efforts to objectively quantify the different aspects of countries' trade regimes. More data, both across countries and in terms of policy areas that significantly affect trade, are needed for better-informed policy discussions. 
Annex I. Summary of data sources

\begin{tabular}{|c|c|c|c|c|c|}
\hline & Database & $\begin{array}{l}\text { Number of } \\
\text { countries } \\
\text { covered }\end{array}$ & Available disaggregation & Barriers included in database & Year of data \\
\hline \multirow{4}{*}{$\begin{array}{l}\text { ñ } \\
\stackrel{0}{\circ}\end{array}$} & $\begin{array}{l}\text { WTO, Tariff databases and } \\
\text { World Tariff Profiles (WTO, } \\
\text { ITC, UNCTAD) }\end{array}$ & $\begin{array}{l}\text { Nearly all WTO } \\
\text { members }\end{array}$ & Tariff line & Tariffs & Through 2017 for some countries \\
\hline & $\begin{array}{l}\text { UNCTAD TRAINS (for non- } \\
\text { tariff measures such as } \\
\text { non-automatic licensing) }\end{array}$ & $\begin{array}{l}\text { Nearly all wTO } \\
\text { members, with } \\
\text { gaps for some } \\
\text { NTM chapters } \\
\text { (see discussion in } \\
\text { text) }\end{array}$ & Tariff line & $\begin{array}{l}\text { SPS, TBT, pre-shipment inspection and other formalities, non- } \\
\text { automatic licensing, quotas, prohibitions and quantity control } \\
\text { measures other than for SPS or TBT reasones, price control } \\
\text { measures including additional taxes and charges, finance } \\
\text { measures, measures, measures affecting competition, trade- } \\
\text { related investment measures, export related measures }\end{array}$ & Through 2015 for some countries \\
\hline & $\begin{array}{l}\text { OECD Average Trade } \\
\text { Facilitation Performance }\end{array}$ & 163 & $\begin{array}{l}11 \text { policy dimensions ( } 133 \\
\text { variables in total) }\end{array}$ & $\begin{array}{l}\text { Customs and other regulatory trade procedures included in the } \\
\text { WTO Trade Facilitation Agreement }\end{array}$ & $\begin{array}{l}\text { Since } 2010 \text { for OECD members. Since } \\
2015 \text { for a much larger set of countries. } \\
\text { Latest data from 2017. Updated every } \\
\text { other year }\end{array}$ \\
\hline & $\begin{array}{l}\text { OECD agricultural support } \\
\text { database }\end{array}$ & $24+E U$ & & Producer support measures (subsidies, credits, etc.) & 1986-2016 \\
\hline \multirow[b]{2}{*}{ 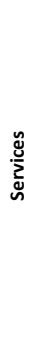 } & $\begin{array}{l}\text { OECD Services } \\
\text { Restrictiveness Index }\end{array}$ & 44 & 22 sectors & $\begin{array}{l}\text { Barriers are grouped into five "policy areas": Restrictions on } \\
\text { foreign entry, restrictions on the movement of people, other } \\
\text { discriminatory measures, barriers to competition, regulatory } \\
\text { transparency }\end{array}$ & Through 2016. Regularly updated \\
\hline & $\begin{array}{l}\text { World Bank Services Trade } \\
\text { Restrictions Database }\end{array}$ & 104 & $\begin{array}{l}\text { By sector and mode of supply. } 5 \\
\text { services sectors (19 subsectors) } \\
\text { and WTO modes of supply } 1 \\
\text { (cross-border trade), } 3 \\
\text { (commercial presence or FDI), and } \\
4 \text { (presence of service-supplying } \\
\text { individuals; they do not cover } \\
\text { financial services, or low-skilled } \\
\text { services) }\end{array}$ & $\begin{array}{l}\text { For mode 1: conditions under which service may be provided, } \\
\text { restrictions on service provider. For mode } 3 \text { : form of entry } \\
\text { allowed, licensing, operation restrictions, regulatory } \\
\text { environment. For mode } 4 \text { : sector openness, licensing, types of } \\
\text { entry allowed, entry conditions. }\end{array}$ & $\begin{array}{l}\text { Data correspond to the period 2008- } \\
\text { 2011. Authors of background paper } \\
\text { state that "Ideally [...] updates would } \\
\text { be systematic." Need to check website } \\
\text { to see if data for a specific country has } \\
\text { more recent information (e.g. China is } \\
\text { still through 2011) }\end{array}$ \\
\hline \multirow{2}{*}{ 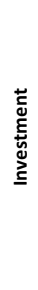 } & $\begin{array}{l}\text { OECD FDI regulatory } \\
\text { Restrictiveness Index }\end{array}$ & $\mathrm{OECD}+27$ & 22 sectors & $\begin{array}{l}\text { Four main types of restrictions on FDI: 1) Foreign equity } \\
\text { limitations; 2) Discriminatory screening or approval } \\
\text { mechanisms;3) Restrictions on the employment of foreigners as } \\
\text { key personnel and 4) Other operational restrictions, e.g. } \\
\text { restrictions on branching and on capital repatriation or on land } \\
\text { ownership by foreign-owend enterprises. }\end{array}$ & 1997-2016 \\
\hline & $\begin{array}{l}\text { World Bank/IFC Investing } \\
\text { Across Borders: Starting a } \\
\text { Foreign Business }\end{array}$ & 87 & & $\begin{array}{l}\text { The index collects information on restrictions to start a foreign } \\
\text { business, including e.g. those on the composition of board of } \\
\text { directors and appointment of managers, use of a local third party } \\
\text { during the establishment process, and requirements for } \\
\text { investment approval. }\end{array}$ & $\begin{array}{l}\text { Single vintage. For most countries, } \\
\text { data correspond to } 2008 \text {. Information } \\
\text { for some countries was updated in } \\
2011\end{array}$ \\
\hline 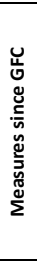 & Global Trade Alert & Around 170 & $\begin{array}{l}\text { Sector. Color coded (red: } \\
\text { implemented and almost certainly } \\
\text { discriminates against foreign } \\
\text { commercial interests, amber: } \\
\text { implemented and may } \\
\text { discriminate, or announced or } \\
\text { under consideration and almost } \\
\text { certainly discriminates, green: } \\
\text { announced and involves } \\
\text { liberalization, implemented but } \\
\text { not discriminatory) }\end{array}$ & $\begin{array}{l}\text { Bail out or state aid, competitive devaluation, consumption } \\
\text { subsidy, export incentive, export taxes or restriction, import ban, } \\
\text { import quota, import subsidy, import tariff, IP protection, } \\
\text { investment measure, localization requirement, migration } \\
\text { measure, NBT not otherwise specified, other service sector } \\
\text { measure, public procurement (localization, preference, and } \\
\text { other), SPS, state trading enterprise, state-controlled company, } \\
\text { sub-national government measure, technical barrier to trade, } \\
\text { trade defense measure (AD, CVD, safeguard), trade finance. }\end{array}$ & $\begin{array}{l}\text { Only includes barriers put in place } \\
\text { since November 2008. The database is } \\
\text { updated regularly }\end{array}$ \\
\hline
\end{tabular}




\section{Annex II. Alternative normalization}

The normalization of the different indicators used to create the spider diagrams in the main text - which rates each country between the most closed (score 0 ) and most open (score 1) in a reference set of countries - is useful to gauge countries' distance to the frontier in each policy area. For countries at the frontier in most areas, such a normalization may not be as informative. Figure AII.1 thus compares, for G20 country groupings, the baseline normalization of the main text (left panel) with one that assigns a score of 1 to free trade (e.g. zero average MFN tariffs, etc.; right panel). ${ }^{27}$ By definition, this will pull all countries toward the center of the diagrams; of interest is to note where the changes are most significant, i.e. in which areas the current frontier is farther from free and open trade. Perhaps unsurprisingly, the largest shift occurs in the case of the OECD STRI - although that is not the case of exports under commercial presence, as measured by the WB STRI. Other differences include further possible gains in pushing the frontier in terms of investment restrictions and, interestingly, in further MFN tariff reductions.

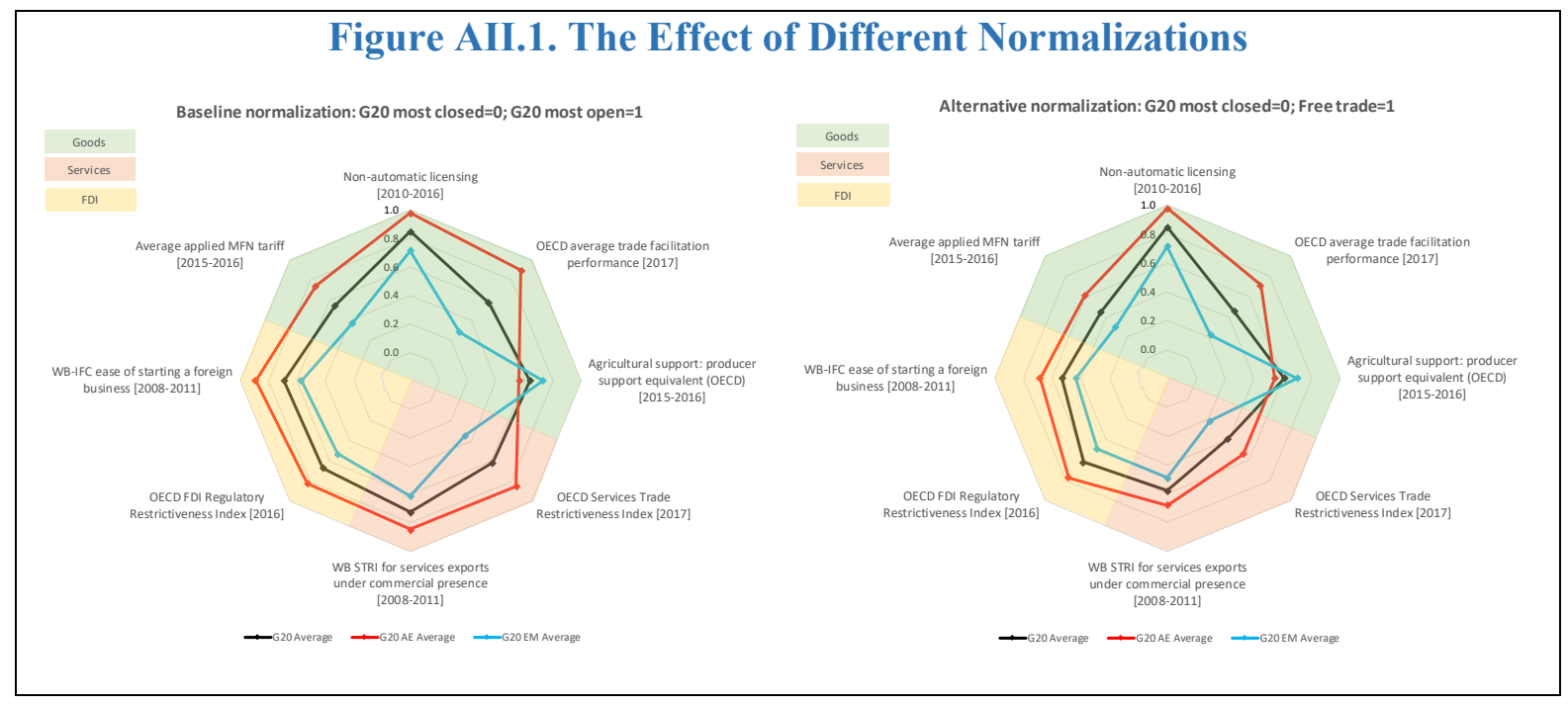

\footnotetext{
${ }^{27}$ We do not report the spider diagram reflecting countries' policies since the 2008 financial crisis since the alternative normalization does not result in any significant change.
} 


\section{Annex III. Selected indicators for individual G20 members}

Table All.1. Selected indicators for G20 advanced economies

\begin{tabular}{|c|c|c|c|c|c|c|c|c|c|c|c|c|c|c|}
\hline \multirow[b]{2}{*}{ Country } & \multicolumn{8}{|c|}{ Overall Trade and Investment Policy Stance } & \multicolumn{6}{|c|}{ Trade Restrictive Measures since 2008} \\
\hline & $\begin{array}{c}\text { Average } \\
\text { applied MFN } \\
\text { tariff }\end{array}$ & $\begin{array}{l}\text { Non-automatic } \\
\text { licensing, } \\
\text { import } \\
\text { coverage ratio }\end{array}$ & $\begin{array}{c}\text { OECD average } \\
\text { trade } \\
\text { facilitation } \\
\text { performance }\end{array}$ & $\begin{array}{c}\text { Agricultural } \\
\text { support: } \\
\text { Producer } \\
\text { support } \\
\text { equivalent } \\
\end{array}$ & OECD STRI & $\begin{array}{c}\text { WB STRI for } \\
\text { services } \\
\text { exports under } \\
\text { commercial } \\
\text { presence } \\
\end{array}$ & $\begin{array}{l}\text { OECD FDI } \\
\text { Regulatory } \\
\text { restrictiveness } \\
\text { index }\end{array}$ & $\begin{array}{l}\text { WB-IFC Ease of } \\
\text { starting a foreign } \\
\text { business }\end{array}$ & $\begin{array}{l}\text { Import duties } \\
\text { and taxation, } \\
\text { import coverage } \\
\text { ratio }\end{array}$ & $\begin{array}{c}\text { Non-tariff } \\
\text { import } \\
\text { restrictions, } \\
\text { import } \\
\text { coverage ratio }\end{array}$ & $\begin{array}{c}\text { Trade defense, } \\
\text { import coverage } \\
\text { ratio }\end{array}$ & $\begin{array}{l}\text { Localization } \\
\text { requirements, } \\
\text { import } \\
\text { coverage ratio }\end{array}$ & $\begin{array}{c}\text { Export } \\
\text { restrictions, } \\
\text { export } \\
\text { coverage ratio }\end{array}$ & $\begin{array}{l}\text { \# of FDI } \\
\text { measures }\end{array}$ \\
\hline Australia & 2.5 & $0.52 \%$ & 1.73 & 2.0 & 0.18 & 18.8 & 0.15 & N/A & $1.1 \%$ & $0.0 \%$ & $0.9 \%$ & $0.2 \%$ & $0.0 \%$ & 12 \\
\hline Canada & 4.1 & $6.28 \%$ & 1.72 & 10.7 & 0.20 & 25.0 & 0.17 & 81.6 & $7.1 \%$ & $0.0 \%$ & $0.6 \%$ & $0.9 \%$ & $0.0 \%$ & 3 \\
\hline European Union & 5.2 & $2.34 \%$ & 1.66 & 21.0 & 0.21 & 26.2 & 0.03 & 79.4 & $5.7 \%$ & $0.8 \%$ & $0.4 \%$ & $0.0 \%$ & $0.1 \%$ & 2 \\
\hline France & 5.2 & $2.34 \%$ & 1.78 & 21.0 & 0.18 & 29.5 & 0.05 & 77.5 & $8.2 \%$ & $0.4 \%$ & $0.3 \%$ & $0.0 \%$ & $0.0 \%$ & 5 \\
\hline Germany & 5.2 & $2.34 \%$ & 1.78 & 21.0 & 0.16 & 22.0 & 0.02 & $\mathrm{~N} / \mathrm{A}$ & $9.7 \%$ & $0.6 \%$ & $0.5 \%$ & $0.0 \%$ & $0.0 \%$ & 2 \\
\hline Italy & 5.2 & $2.34 \%$ & 1.62 & 21.0 & 0.25 & 27.0 & 0.05 & N/A & $7.3 \%$ & $1.3 \%$ & $0.7 \%$ & $0.1 \%$ & $0.0 \%$ & 4 \\
\hline Japan & 4.0 & $0.00 \%$ & 1.72 & 48.0 & 0.18 & 23.4 & 0.05 & 81.6 & $2.3 \%$ & $0.0 \%$ & $0.2 \%$ & $0.0 \%$ & $0.0 \%$ & 0 \\
\hline Korea & 13.9 & $\mathrm{~N} / \mathrm{A}$ & 1.82 & 49.2 & 0.15 & 21.3 & 0.14 & 71.1 & $18.5 \%$ & $0.0 \%$ & $0.4 \%$ & $0.0 \%$ & $0.0 \%$ & 3 \\
\hline United Kingdom & 5.2 & $2.34 \%$ & 1.75 & 21.0 & 0.19 & 13.7 & 0.04 & 85.0 & $11.1 \%$ & $0.7 \%$ & $0.5 \%$ & $0.0 \%$ & $0.0 \%$ & 1 \\
\hline United States & 3.5 & $0.02 \%$ & 1.82 & 8.7 & 0.22 & 19.8 & 0.09 & 80.0 & $5.8 \%$ & $0.0 \%$ & $2.8 \%$ & $3.9 \%$ & $0.4 \%$ & 5 \\
\hline
\end{tabular}
Notes: Average tariffs and tariff peaks are ad-valorem, in percent; producer support is expressed as percent of gross farm receipts (including transfers); OECD average trade facilitation performance ranges from 0 (least open) to 2 (most open);
OECD STRI and FDI indexes range from 0 (completely open) to 1 (completelyclosed); the WB STRI index ranges from 0 (completely open) to 100 (completelyclosed): the WB-IFC ease of starting a foreign business ranges from 0 (most closed) to 100 (most open). Data on OECD STRI, OECD FDI, WB-IFC Ease of starting a foreign business and GTA for the European Union correspond to the simple average of EU member countries with data availability.

Sources: WTO, OECD, World Bank, UNCTAD TRAINS, UN COMTRADE, Global Trade Alert. 
Table Alll.2. Selected indicators for $\mathbf{G} 20$ emerging market countries

\begin{tabular}{|c|c|c|c|c|c|c|c|c|c|c|c|c|c|c|}
\hline \multirow[b]{2}{*}{ Country } & \multicolumn{8}{|c|}{ Overall Trade and Investment Policy Stance } & \multicolumn{5}{|c|}{ Trade Restrictive Measures since 2008} & \multirow[b]{2}{*}{$\begin{array}{c}\text { \# of FDI } \\
\text { measures }\end{array}$} \\
\hline & $\begin{array}{c}\text { Average } \\
\text { applied MFN } \\
\text { tariff }\end{array}$ & $\begin{array}{l}\text { Non-automatic } \\
\text { licensing, } \\
\text { import } \\
\text { coverage ratio }\end{array}$ & $\begin{array}{c}\text { OECD average } \\
\text { trade } \\
\text { facilitation } \\
\text { performance }\end{array}$ & $\begin{array}{l}\text { Agricultural } \\
\text { support: } \\
\text { Producer } \\
\text { support } \\
\text { equivalent } \\
\end{array}$ & OECD STRI & $\begin{array}{c}\text { WB STRI for } \\
\text { services } \\
\text { exports under } \\
\text { commercial } \\
\text { presence } \\
\end{array}$ & $\begin{array}{l}\text { OECD FDI } \\
\text { Regulatory } \\
\text { restrictiveness } \\
\text { index }\end{array}$ & $\begin{array}{l}\text { WB-IFC Ease of } \\
\text { starting a foreign } \\
\text { business }\end{array}$ & $\begin{array}{c}\text { Import duties } \\
\text { and taxation, } \\
\text { import coverage } \\
\text { ratio } \\
\end{array}$ & $\begin{array}{c}\text { Non-tariff } \\
\text { import } \\
\text { restrictions, } \\
\text { import } \\
\text { coverage ratio } \\
\end{array}$ & $\begin{array}{c}\text { Trade defense, } \\
\text { import coverage } \\
\text { ratio }\end{array}$ & $\begin{array}{l}\text { Localization } \\
\text { requirements, } \\
\text { import } \\
\text { coverage ratio }\end{array}$ & $\begin{array}{c}\text { Export } \\
\text { restrictions, } \\
\text { export } \\
\text { coverage ratio }\end{array}$ & \\
\hline Argentina & 13.7 & $98.89 \%$ & 1.31 & N/A & N/A & 14.9 & 0.03 & 65.0 & $24.5 \%$ & $38.7 \%$ & $2.2 \%$ & $18.7 \%$ & $15.1 \%$ & 10 \\
\hline Brazil & 13.5 & $66.04 \%$ & 1.24 & 4.9 & 0.30 & 21.0 & 0.10 & 62.5 & $27.1 \%$ & $0.3 \%$ & $1.7 \%$ & $23.9 \%$ & $0.0 \%$ & 6 \\
\hline China & 9.9 & $12.76 \%$ & 1.36 & 14.5 & 0.36 & 37.3 & 0.33 & 63.7 & $21.2 \%$ & $2.9 \%$ & $1.6 \%$ & $0.0 \%$ & $1.2 \%$ & 15 \\
\hline India & 13.4 & $2.77 \%$ & 1.25 & $\mathrm{~N} / \mathrm{A}$ & 0.42 & 69.3 & 0.21 & 76.3 & $33.8 \%$ & $0.1 \%$ & $4.4 \%$ & $2.8 \%$ & $8.4 \%$ & 11 \\
\hline Indonesia & 7.9 & $24.33 \%$ & 1.13 & 29.1 & 0.40 & 56.5 & 0.32 & 52.6 & $14.9 \%$ & $32.1 \%$ & $1.2 \%$ & $4.2 \%$ & $45.5 \%$ & 26 \\
\hline Mexico & 7.0 & $10.47 \%$ & 1.49 & 8.0 & 0.27 & 27.3 & 0.19 & 65.8 & $4.3 \%$ & $7.3 \%$ & $0.3 \%$ & $0.5 \%$ & $15.9 \%$ & 1 \\
\hline Russia & 7.1 & $0.13 \%$ & 1.28 & 16.1 & 0.33 & 18.8 & 0.19 & 68.4 & $14.0 \%$ & $6.5 \%$ & $1.2 \%$ & $15.4 \%$ & $7.6 \%$ & 2 \\
\hline Saudi Arabia & 5.1 & N/A & 1.22 & N/A & N/A & 44.4 & 0.36 & 35.0 & $6.3 \%$ & $14.9 \%$ & $0.0 \%$ & $0.0 \%$ & $0.0 \%$ & 3 \\
\hline South Africa & 7.7 & N/A & 1.50 & 2.3 & 0.24 & 37.1 & 0.06 & 78.9 & $9.2 \%$ & $0.5 \%$ & $0.1 \%$ & $0.0 \%$ & $0.7 \%$ & 1 \\
\hline Turkey & 10.9 & $8.59 \%$ & 1.48 & 27.9 & 0.27 & 26.7 & 0.06 & 65.8 & $8.7 \%$ & $0.1 \%$ & $3.1 \%$ & $2.9 \%$ & $0.1 \%$ & 0 \\
\hline
\end{tabular}

Notes: Average tariffs and tariff peaks are ad-valorem, in percent; producer support is expressed as percent of gross farm receipts (including transfers); OECD average trade facilitation performance ranges from 0 (least open) to 2 (most open); OECD STRI and FDI indexes range from 0 (completely open) to 1 (completely closed); the WB STRI index ranges from 0 (completely open) to 100 (completely closed); the WB-IFC ease of starting a foreign business ranges from 0 (most closed) to

Sources: WTO, OECD, World Bank, UNCTAD TRAINS, UN COMTRADE, Global Trade Alert. 


\section{Annex IV. Country coverage of overall-trade-regime indicators}

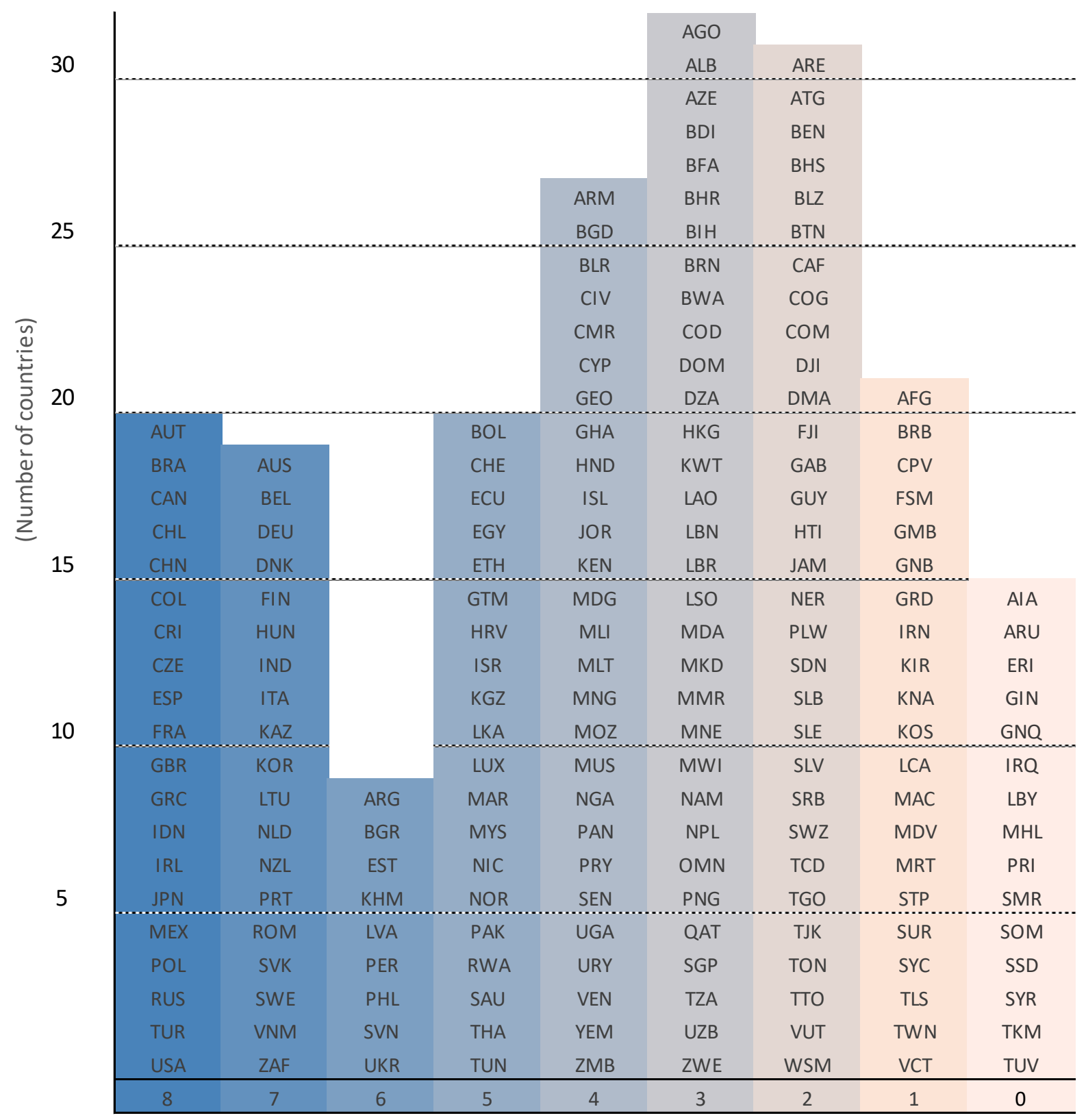




\section{Annex V. Other available indicators}

This Annex discusses other available indicators available for large sets of countries. Some of these indicators are derived from regression models, others from surveys or questionnaires. The reasons for which these indicators were not included in the discussion of the main text range from the underlying data being dated, to the methodology being likely to pick up non-actionable barriers, and the indicator not providing meaningful comparisons for large subsets of countries.

World Bank Overall Trade Restrictiveness Index. The World Bank's OTRI is an estimate of the uniform ad-valorem tariff that would leave a country's total imports unchanged if that uniform tariff were to replace the country's existing structure of tariff and non-tariff barriers. ${ }^{28}$ The OTRI thus provides a tangible way to summarize in a single index most of a country's barriers to trade in goods. Unfortunately, the data on which the estimates are based are too outdated, and the index has therefore not been included among the indicators used in the main text to gauge countries' overall policy stance. ${ }^{29}$ For reference, however, here we describe the methodological steps involved in estimating the index (for further details, see Kee et al., 2009).

(i) Time-variation in non-tariff barriers. The authors aim to identify a different effect of NTBs on quantities for each country-product pair (e.g. the effect of NTBs on banana imports by country X). Identifying the country-specific effect for a specific product requires time variation in NTBs, but NTBs change only slowly over time. They generate this time variation by positing that the effect of the NTB imposed by a country changes with time-varying country characteristics (GDP, capital over GDP, labor over GDP, and agricultural land over GDP). That is, they interact NTBs with these time-varying characteristics. The underlying rationale is that e.g. the effect of imposing NTBs on grain should be smaller for a country which has a lot of arable land (capture by agricultural land).

(ii) Addressing endogeneity of trade barriers. Second, since barriers may be endogenous, they propose a number of instruments, including e.g. a weighted average of barriers used by neighboring countries. They argue that this captures e.g. legal and institutional features that may influence the use of NTBs and are not

\footnotetext{
${ }^{28}$ To be precise, the authors use tariff data from the WTO database, UNCTAD TRAINS, and (for ad-valorem equivalents of specific components) MAcMap. NTB data are from UNCTAD TRAINS, and updates from WTO's Trade Policy Reviews and other sources. Domestic support data are from WTO notifications. They consider there to be an NTB if at least one of the following measures (called "core NTBs") applies to the specific tariff line: price control measures, quantity restrictions, monopolistic measures, or technical regulations; they also account separately for domestic agricultural support (measured in USD). The data are on an MFN-basis (i.e. they do not account for preferences).

${ }^{29}$ Data are from between 2000 and 2004 for tariffs, 1992-2001 for core NTBs (see Table 1 in Kee et al., 2009), and 1995-1998 for domestic agricultural support.
} 
caused by the country's level of imports. These instruments are included in a firststage probit regression that aims to control for self-selection a-la-Heckman.

(iii) Translating non-tariff barriers into ad-valorem equivalents. The estimated impact of NTBs on quantities needs to be translated into ad-valorem equivalents. This is achieved by taking the ratio of the estimated impact on quantities to the trade elasticity (a large impact on quantities would translate into a lower AVE if the product in question has a large elasticity). The elasticity estimates come from the estimated coefficient on tariffs.

(iv) Aggregating the information into a country-level index. Following Anderson and Neary (2003), the aggregate index (eq. (18) in Kee et al. 2009) is a weighted average of restrictions at the tariff-line level. The weights are given by the product of the value of imports times the elasticity (i.e. goods with higher elasticity carry higher weight; this adequately corrects for the fact that imposing NTBs reduces the value of imports in an amount proportional to the elasticity).

Tariff equivalents for services sectors. Fontagne et al. (2011) proposed to use estimates from a gravity regression to estimate ad-valorem equivalents of trade restrictiveness for different services sectors, and Fontagne et al. (2016) the authors provide updated estimates based on data from 2011. In short, the methodology is based on using the gravity equation in Anderson and van Wincoop (2003) to back out ad-valorem equivalents from the estimated importer fixed effect in a gravity regression. The methodology has the advantage of only relying on trade in services data and standard covariates of the gravity literature; i.e. it does not require data on trade policy barriers. Thus, resulting estimates are not only tangible (as they are expressed in a unit of measure comparable to ad-valorem tariffs), but can also be especially useful when there is no available indicator based on directlyobserved trade policy barriers in an economy or sector. Having a full set of controls should, in turn, ensure that the estimates do not "[...] pick up trade cost factors beyond policy restraints, so that the tariff equivalent results may reflect a broad range of "frictions" which might not be fully actionable (Fontagne et al., 2016, p. 5). It is worth noting that, by being constructed using data on cross-border trade in services, the estimates by Fontagne et al. $(2011,2016)$ refer exclusively to exclusively to Mode 1 services trade (e.g. restrictions to commercial presence are excluded by definition).. For reference, we briefly mention three key assumptions involved in this methodology: (i) NTMs are non-discriminatory across trading partners, (ii) there is one country in the sample that imposes zero NTMs (the "free trader," taken to be the country with the highest positive difference between the actual and predicted average import values), and (iii) an assumption on the elasticity of substitution sigma. The elasticity assumed in (iii) affects the ad-valorem equivalent estimates, but not countries' ranking in terms of openness. In addition, since the update in Fontagne et al. (2016) uses a cross section (as opposed to a panel in the original paper) of 2011 data, importer GDP cannot be controlled for (it would collapse into the fixed effect); the authors thus assume that the importer's GDP enters the equation with a coefficient of 0.8 . 
World Bank Doing Business, Trading Across Borders - time and cost to import. The World Bank Doing Business includes data on time and cost to import. The data are gathered through a questionnaire administered to local freight forwarders, customs brokers, port authorities and traders. ${ }^{30}$ Respondents are required to submit answers on the basis of a standardized shipment of 15 metric tons of containerized auto parts (HS 8708) from the country's natural import partner - the economy from which it imports the largest value (price times quantity) of auto parts. This, unfortunately, introduces some bias in the results. For instance, any country that is part of a fully-integrated customs union that produces auto parts will naturally appear very open on this metric, even if it maintained high barriers with countries outside the customs union.

\section{References}

Anderson, J. and P. Neary. 2003. "The Mercantilist index of trade policy," International Economic Review, Vol. 44 (2) (May), pp. 627-49.

Anderson, J. and P. Neary. 2005. "Measuring the Restrictiveness of International Trade Policy," MIT Press.

Anderson, J. and E. van Wincoop. 2003. "Gravity with Gravitas: A Solution to the Border Puzzle,” American Economic Review, Vol. 93(1), pp. 170-92.

Anderson, R.D., P. Pelletier, K. Osei-Lah and A.C. Mueller. 2011. "Assessing the Value of Future Accessions to the WTO Agreement on Government Procurement (GPA): Some New Data Sources, Provisional Estimates, and an Evaluative Framework for Individual WTO Members Considering Accession," World Trade Organization Staff Working Paper ERSD-2011-15.

Ang, J.S., Y. Cheng and C. Wu. 2014. "Does Enforcement of Intellectual Property Rights Matter in China? Evidence from Financing and Investment Choices in the High-Tech Industry," The Review of Economics and Statistics, Vol. 96, Issue 2, May 2014.

Bayoumi, T. 2017. Unfinished Business: The Unexplored Causes of the Financial Crisis and the Lessons Yet to be Learned. Yale University Press.

\footnotetext{
${ }^{30}$ For full methodological background, see http://www.doingbusiness.org/Methodology/Trading-AcrossBorders
} 
Borchert, I., B. Gootiiz, and A. Mattoo. 2014. "Policy Barriers to International Trade in Services: Evidence from a New Database,” World Bank Economic Review, Vol. 28 (1), pp. 162-188.

Bown, C. and M.A. Crowley. 2016. "The Empirical Landscape of Trade Policy," Chapter 1 in K. Bagwell and R.W. Staiger (eds.), Handbook of Commercial Policy, Volume $1 \mathrm{~A}, 1^{\text {st }}$ Edition.

Costinot, A. and A. Rodriguez-Clare. 2014. "Trade Theory with Numbers: Quantifying the Consequences of Globalization," Chapter 4, pp. 197-261, in G. Gopinath, E. Helpman and K. Rogoff (eds.), Handbook of International Economics, 2014 (Vol. 4).

Djankov, S., A. Islam and F. Saliola. 2016. "How Large Is Public Procurement in Developing Countries” Peterson Institute for International Economics.

Dür, A., L. Baccini and M. Elsig. 2014. "The Design of International Trade Agreements: Introducing a New Dataset," The Review of International Organizations, Vol. 9, Issue 3, pp. 353-375.

ESCAP-OECD. 2017. "Indicators for Trade Facilitation: A Handbook," Version 1.0, available at www.oecd.org/trade/facilitation/Indicators-for-Trade-Facilitation-ESCAPOECD-Handbook.pdf

Ederington, J. and M. Ruta. 2016. "Nontariff Measures and the World Trading System," Chapter 5 in K. Bagwell and R.W. Staiger (eds.), Handbook of Commercial Policy, Volume $1 \mathrm{~B}, 1^{\text {st }}$ Edition.

European Union. 2017. "Openness of public procurement markets in key third countries," Directorate-General for External Policies, July 2017.

Evenett, S.J. and B.M. Hoekman. 2004. "International Disciplines in Government Procurement: A Review of Economic Analyses and their Implications," mimeo.

Fontagne, L., A. Guillin, and C. Mitaritonna. 2011. "Estimations of Tariff Equivalents for the Services Sectors," CEPII Document de Travail No 2011-24.

Fontagne, L., C. Mitaritonna, and J. Signoret. 2016. "Estimated Tariff Equivalents of Services NTMs," CEPII Working Paper No 2016-20.

Francois, J.F. and W. Martin. 2004. "Commercial policy variability, bindings, and market access,” European Economic Review, Vol. 48, Issue 3, pp. 665-679. 
Grosso, M.G. 2005. "Non-automatic Import Licensing," Chapter 3 in Looking beyond Tariffs: The Role of Non-Tariff Barriers in World Trade, OECD, 2005.

Grosso, M.G., F. Gonzales, S. Miroudot, H.K. Nordas, D. Rouzet, and A. Ueno. 2015. "Services Trade Restrictiveness Index (STRI): Scoring and Weighting Methodology," OECD Trade Policy Papers No. 177.

Handley, K. 2014. "Exporting under Trade Policy Uncertainty: Theory and Evidence," Journal of International Economics, 94.

Helpman, E. 1993. "Innovation, Imitation, and Intellectual Property Rights," Econometrica, Vol. 61, No. 6, Nove. 1993, pp. 1247-1280.

Heuser, C. and A. Mattoo. 2017. "Services trade and global value chains," World Bank Policy Research Working Paper 8126.

Hoekman, B.M., F. Ng and M. Olarreaga. 2004. "Agricultural Tariffs or Subsidies: Which Are More Important for Developing Countries?," The World Bank Economic Review, Vol. 18, No. 2, pp. 175-204.

Hoekman, B.M. and A. Mattoo. 2013. "Liberalizing Trade in Services: Lessons from Regional and WTO Negotiations,” EUI Working Paper, RSCAS 2013/34.

Hofmann, C., A. Osnago and M. Ruta. 2017. "Horizontal Depth: A New Database on the Content of Preferential Trade Agreements," World Bank Policy Research Working Paper.

International Monetary Fund (IMF). 2010. "Reference Note on Trade Policy, Preferential Trade Agreements, and WTO Consistency," September 2010, Washington, DC.

International Monetary Fund (IMF). 2016a. "Global Trade: What's Behind the Slowdown?" World Economic Outlook, Chapter 2.

International Monetary Fund (IMF). 2016b. "Reinvigorating Trade to Support Growth: A Path Forward," Note for Ministers and Governors for the July G20 Ministerial, July 2016.

International Monetary Fund (IMF). 2017. Use of Third-Party Indicators in Fund Reports, November 2017, Washington, DC.

International Monetary Fund, World Trade Organization, and World Bank (IMF-WTO-WB). 2017. "Making Trade and Engine of Growth for All: The Case for Trade and for Policies to Facilitate Adjustment," Policy Papers, Prepared by Staff of the IMF, the World Bank Group, and the World Trade Organization. 
Jafari, Y. and D.G. Tarr. 2017. "Estimates of Ad Valorem Equivalents Against Foreign Suppliers of Services in Eleven Services Sectors and 103 Countries," The World Economy, Vol. 3, Issue 4, pp. 544-573.

Kee, H.L., A. Nicita, and M. Olarreaga. 2009. "Estimating Trade Restrictiveness Indices," Economic Journal, Vol. 119 (January), pp. 172-199.

Moïsé, E. and S. Sorescu. 2013. "Trade Facilitation Indicators: The Potential Impact of Trade Facilitation on Developing Countries' Trade”, OECD Trade Policy Papers, No. 144, OECD Publishing, Paris.

Nicolas, F., S. Thomsen and M. Bang. 2013. "Lessons from Investment Policy Reform in Korea,” OECD Working Papers on International Investment, 2013/02, OECD Publishing.

Nordås, H.K. and D. Rouzet. 2015. "The Impact of Services Trade Restrictiveness on Trade Flows: First Estimates," OECD Trade Policy Papers, No. 178, OECD Publishing, Paris.

OECD. 2012. "Trade Facilitation Indicators: The Potential Impact of Trade Facilitation on Developing Countries' Trade," Policy Dialogue on Aid for Trade, TAD/TC/WP(2012)24.

OECD. 2016. “OECD's Producer Support Estimate and Related Indicators of Agricultural Support: Concepts, Calculations, Interpretation and Use (The PSE Manual)," Trade and Agriculture Directorate, March 2016.

OECD. 2017. "Is investment protectionism on the rise? Evidence from the OECD FDI Regulatory Restrictiveness Index," OECD Global Forum on International Investment.

Pierce, J. R., and P. K. Schott. 2016. "The Surprisingly Swift Decline of US Manufacturing Employment," American Economic Review, Vol. 106(7), pp. 1632-62.

Ramondo, N., and A. Rodriguez-Clare. 2013. "Trade, Multinational Production, and the Gains from Openness,” Journal of Political Economy, Vol. 121 (2), pp. 273-322.

Reis, J.G. and T. Farole. 2011. "Trade Competitiveness Diagnostic Toolkit,” World Bank, International Trade Department.

Tokarick, S. 2003. "Measuring the Impact of Distortions in Agricultural Trade in Partial and General Equilibrium,” IMF Working Paper WP/03/110, May 2003.

UNCTAD. 2012. "International Classification of Non-Tariff Measures," 2012 Version, available at http://unctad.org/en/PublicationsLibrary/ditctab20122 en.pdf 
Volpe Martincus, C., J. Carballo and A. Graziano. 2015. "Customs,” Journal of International Economics, Vol. 96, Issue 1, May 2015, pp. 119-137.

World Trade Organization (WTO). 2011. World Trade Report 2011: The WTO and Preferential Trade Agreements: from co-existence to coherence.

World Trade Organization (WTO). 2013. Technical Cooperation Handbook on Notification Requirements, Agreement on Subsidies and Countervailing Measures. August 2013 revision.

World Trade Organization (WTO). 2017. "Concerns grow about slippage in subsidy notifications," Press Release, April 25, 2017. 